\title{
Türkiye Futbol Süper Liginde Yabanc1 Futbolcu Düzenlemesinin Değerlendirilmesi
}

\section{Uğur ÖZER ${ }^{1}$}

\section{$\ddot{O} z$}

$\mathrm{Bu}$ araştırmanın amacı son on sezonda Türk futbolunda uygulanan yabancı futbolcu sınırlaması ile ilgili düzenlemelerin değerlendirilmesidir. Çalışmada betimsel araştırma modeli kullanılmış ve gerekli veriler ilgili veri tabanlarından elde edilmiştir. Araştırma kapsamında 2010-2015 ve 2015-2020 sezonları arasında Süper Ligde uygulanan yabancı futbolcu düzenlemelerinin Türk futboluna etkileri kulüpler ve A Milli Takım düzeyinde, karșilaştırmalı olarak incelenmiștir. Çalıșma sonucunda 2015-2020 yılları arasında uygulanan ve A Takımı Listesinde 14 yabancı futbolcunun yer alabildiği dönemde, kulüplerin UEFA organizasyonları başarısına göre sınırlı bir puan artışı olduğu, buna karşın aynı dönemde Türk Milli Takımının FIFA sıralamasında belirgin bir yükselişi olduğu tespit edilmiştir. Buradan hareketle, 2015-2016 sezonundan itibaren uygulanan yabanc1 futbolcu düzenlemesinin, kulüplerin UEFA organizasyonları bașarısında belirgin bir etkisi olmamasına rağmen, FIFA sıralamasındaki yükseliṣ göz önünde bulundurularak, milli takım düzeyinde olumsuz bir etkisinin olmadığı söylenebilir.

Anabtar Kelimeler: Futbol, Türkiye Futbol Süper Ligi, Yabancı Futbolcu Sınırlaması

\section{Evaluation of Foreign Soccer Players Regulation in Turkish Football Super League}

\begin{abstract}
The aim of this research is to evaluate the regulations regarding the restriction of foreign players applied in Turkish football in the last ten seasons. Descriptive research model was used in the study and necessary data were obtained from related databases. Within the scope of the research, the effects of foreign football player regulations applied in the Super League between 2010-2015 and 2015-2020 seasons on Turkish football were analyzed comparatively at the level of clubs and A National Team. As a result of the study, in the period implemented between 2015-2020 and when 14 foreign players could be included in the A Team List, there was a limited increase in points according to the success of the UEFA organizations of the clubs, however, a significant rise in the FIFA ranking of the Turkish National Team in the same period. Considering the rise in the FIFA rankings, it can be said that although the regulation of foreign players, implemented since the 2015-2016 season, has not had a significant effect on the success of the UEFA organizations of the clubs, it does not have a negative effect at the national team level.
\end{abstract}

Key Words: Football, Turkish Football Super League, Foreign Players Restriction

Atıf İçin / Please Cite As:

Özer, U. (2022). Türkiye futbol süper liginde yabanc1 futbolcu düzenlemesinin değerlendirilmesi. Manas Sosyal Araștırmalar Dergisi, 11(1), 439-457.

Geliş Tarihi / Received Date: 26.03.2021

Kabul Tarihi / Accepted Date: 19.07.2021

1Dr. Öğr. Üyesi - Hitit Üniversitesi Sosyal Bilimler Meslek Yüksekokulu, ugurozer84@hotmail.com 


\section{Giriş}

Profesyonel bir spor dalı olarak gelişen ve yaygınlaşan futbol, sosyoekonomik olarak tüm dünyada olağanüstü boyutlara ulaşmış, bilimsel araştırmalara konu olan bir faaliyet durumundadır. Toplumsal olarak küçümsenmeyecek bir etkiye sahip olan futbol sektörel anlamda da önemli sayılabilecek bir yap1 sergilemektedir. Bugünkü durumda futbol kulüpleri gelirleri ve bütçeleriyle sadece sportif bir yap1 olmaktan çıkarak ekonomik bir organizasyona da dönüşmüşlerdir. Dolayısıyla mevcut kaynaklarını (para, zaman, mekân, malzeme, personel vb.) rasyonel bir şekilde kullanmak kulüpler açısından da önemli hale gelmiştir (Akşar ve Merih, 2008, s. 143).

Günümüzde bir spor dalı olmasının yanında yarattı̆̆ ekonomik değer ile ticarileşmesi sonucu büyük ölçekli bir endüstri haline gelen futbolda, kulüplerin bütçe açıkları ve yüksek meblağlara ulaşan borçluluk düzeyi tehlike sinyalleri olarak algılanmaktadır. Avrupa futbolunun yönetiminden sorumlu olan Avrupa Futbol Federasyonlar1 Birliği (UEFA-Union of European Football Associations), futbol kulüplerinin finansal yapılarını sağlamlaştırmak ve rekabetçi dengeyi korumak adına çeşitli yaptırımlar uygulayarak finansal tehlikelere karşı önlemler almaya çalşmaktadır (Güngör, 2014a, s. 21). Bu kapsamda UEFA tarafindan çıarılan Finansal Fair Play düzenlemesi, futbolda ekonomik başarıyı geliştirmek, kulüplerin ömürlerini uzatmak ve sürekliliklerini sağlamak için oluşturulmuştur. Finansal Fair Play düzenlemesinin amaçları, kulüplerin daha disiplinli ve mantıklı bir şekilde yönetilmesini sağlamak, transfer ücretlerini astronomik seviyelerden olması gereken seviyelere düşürmek, gençlere ve altyapıya yatırım yapılmasının önünü açmak, kulüplerin gelir-gider dengesini gözeterek hareket etmelerini ve mali yükümlülüklerini zamanında yerine getirmelerini sağlamaktır (Bıçakçı, 2015, s. 8).

1923'ten beri Uluslararası Futbol Federasyonları Birliği’nin (FIFA-Federation Internationale de Football Associations) ve 1962'den beri de UEFA'nın bir üyesi olan Türkiye Futbol Federasyonu (TFF) Türkiye'de futbolu düzenleyen ve yürüten tek kuruluştur (TFF Statü, 2019, s. 7). Dolayısıyla UEFA tarafindan alınmış olan kararları uygulamak ve kulüplerin bu kararlara uymasını sağlamak da TFF'nin yetkisi dâhilindedir.

TFF tarafindan düzenlenen Süper Lig, Türkiye'deki en üst profesyonel futbol ligidir ve Süper Lig'de müsabakalar 2019-2020 sezonuna kadar 18 futbol takımı arasında, çift devreli lig usulüne göre oynanıyorken, ortaya çıkan Covid 19 salgını küme düşürülme uygulamasının askıya alınmasına neden olduğu için, 2020-2021 sezonunda Süper Lig'de 21 takım yer almıştır.

Futbolcuların statüsü ve transferlerine ilişkin hükümler, FIFA'nın Oyuncu Statüsü ve Transferlerine ilişkin talimatlarına uygun olarak TFF Yönetim Kurulu tarafından düzenlenmektedir (TFF Statü, 2019, s. 9). Futbol kulüpleri Süper Lig müsabakalarına katılabilmek için federasyon tarafından düzenlenen Futbolcuların Uygunluğu hükümlerine uymak zorundadır. Futbolcu Uygunluğu düzenlemesi her sezon için ayrı düzenlenen Süper Lig Müsabakaları Statüsü belgesinde yer almaktadır.

2019-2020 Sezonu Süper Lig Müsabakaları Statüsüne göre; kulüpler istedikleri sayıda profesyonel futbolcu sözleşmesi imzalayabilir ve tescil ettirebilirken, bir kulübün A Takım Listesi en fazla 28 futbolcu olabilir ve listede yer alan en az 14 futbolcu Türkiye A Milli Futbol Takımında oynama uygunluğuna sahip olmalıdır. Kulüplerin A Takım Listesinde en fazla 3 kaleci yer alabilir ve bu kalecilerden en az birisinin Türkiye A Milli Takımında oynama uygunluğu bulunan futbolcu olması zorunludur. Türk futbolcular içerisinde kulübün kendi alt yapısından yetişmiş en az 4 futbolcunun ve Türkiye'deki diğer kulüplerin alt yapısından yetişmiş en az 4 futbolcunun bulundurulması zorunlu tutulmuştur. Bu düzenleme ile diğer ülkelerde yetişmiş olan Türk futbolculara sınırlama getirilmiştir. Futbolcu Uygunluğu düzenlemesine göre Süper Lig futbol takımları A Takım Listelerinde en fazla 14 yabancı futbolcu bulundurabilmektedir (TFF Müsabaka Statüleri, 2019-2020).

Yukarıda belirtilen kurallar 2015-2016 Sezonundan günümüze kadar Türkiye Süper Ligi’nde uygulanmaktadır. Daha önceleri ise TFF tarafından sürekli değişen bir yabancı futbolcu politikası izlenmiştir (Tablo 1). 
Tablo 1. Türkiye Futbol Federasyonu Süper Lig'inde Son 10 Sezonda Uygulanan Yabancı Futbolcu Sinrr Saynlarn

\begin{tabular}{|c|c|c|c|}
\hline Sezon & $\begin{array}{c}\text { Bir Kulüpte Bulunabilecek En } \\
\text { Fazla Lisanslı Yabanc1 } \\
\text { Futbolcu Sayis1 }\end{array}$ & $\begin{array}{c}18 \text { Kişilik Maç Kadrosunda } \\
\text { Bulunabilecek En Fazla } \\
\text { Yabanc1 Futbolcu Sayıs1 }\end{array}$ & $\begin{array}{c}\text { Aynı anda Müsabakalarda } \\
\text { Oynayabilen Yabanc1 Futbolcu } \\
\text { Sayis1 }\end{array}$ \\
\hline $2010-2011$ & 10 & 8 & 6 \\
\hline 2011-2012 & $\begin{array}{c}\text { Kulüpler istedikleri sayıda } \\
\text { yabancı futbolcu ile sözleşme } \\
\text { imzalayabilirler }\end{array}$ & 8 & 6 \\
\hline $2012-2013$ & $\begin{array}{c}\text { yabanc futbolcu ile sözleşme } \\
\text { imzalayabilirler }\end{array}$ & 8 & 6 \\
\hline 2013-2014 & 10 & 6 & 6 \\
\hline 2014-2015 & 8 & 8 & 5 \\
\hline 2015-2016 & 14 & 11 & 11 \\
\hline 2016-2017 & 14 & 11 & 11 \\
\hline $2017-2018$ & 14 & 11 & 11 \\
\hline 2018-2019 & 14 & 11 & 11 \\
\hline 2019-2020 & 14 & 11 & 11 \\
\hline
\end{tabular}

Kaynak: Türkiye Futbol Federasyonu Müsabaka Statüleri (2010-2020).

Türk futbolunda yabancı futbolcu sınırlaması ile ilgili başlıca iki farklı görüş bulunmaktadır. İlk görüşe göre, yabancı futbolcu sayısının artırılmasının Türk Futboluna zarar vereceği ve yabancı futbolcuların, genç Türk futbolcularının önünü keseceğidir. Bu görüşü savunanlar Türk futbolunun gelişimi için yabanc1 futbolcu sınırlamasının şart olduğunu ifade etmektedir.

İkinci görüş ise yabanc1 futbolcu sayısını sınırlı tutmanın düşük rekabet ortamı yarattı̆̆ını, Türk Vatandaşı futbolcuların kendilerini geliştirmek için yeterince çalışmadıklarını, yerlerini kaybetme korkularının bulunmadığını, ancak yabancı iyi futbolcular ile aynı ücretleri talep ettiklerini, kulüplerin bu sebeple maliyetlerinin fazla olduğunu ve verim alamadıklarını, bu sınırlama nedeniyle Türk Vatandaşı futbolcu ücretlerinin anlamsız derecede yükseldiğini, yabancı futbolcu sınırlamasının Avrupa'da mücadele eden takımların önünü tıkadığını, UEFA ve Şampiyonlar Ligi ya da uluslararası oyunlarda rakipleri önünde eşit şartlar altında olmadıklarını, haksız rekabetin olduğunu ve başarının belli bir noktadan sonra elde edilemediğini, bu nedenle de yabancı futbolcu sayısının artırılması ya da bu sınırlamanın kalkmasını savunanlardan oluşmaktaydi.

Yabancı futbolcu sayısının artırılmasını savunan görüş, sayı artınca, kulüplerin önünün açılacağı ve daha geniş bir havuzdan seçim yapma şansına ulaşacaklarını, Türk futbolcuların ücretlerinin makul düzeylere gerileyeceğini, tüm takımların bütçelerini daha doğru değerlendireceklerini, Türk futbolcuların daha çok çalışarak kendilerini geliştireceklerini ve bu durumun da Türk futbolunu ilerleteceğini, Türk futbolunun yabancılara izin verilmediği dönemlerde, en başarısız dönemlerini yaşadığını ve futbolcu ücretlerinin çok yükseldiğini, Türk milli takımının düzeyinin gerilediğini, diğer taraftan yabanc1 sınırlamasının olmadığı futbolda başarılı olan ülkelerin ve $A B$ vatandaşı futbolcuların yabancı sayılmadığ1 Avrupa ülkelerinin göz önüne alınması gerektiğini belirtmekteydi (Şar, 2007, s. 543-544).

Yukarıdaki tartışmalardan hareketle bu araştırmanın amacı son on sezonda Türk futbolunda uygulanan yabancı futbolcu sınırlaması ile ilgili düzenlemelerin değerlendirilmesidir. Gelecekte yapılacak olan muhtemel düzenlemelere fikir sağlaması açısından araştırmanın önemli olduğu düşünülmektedir.

\section{Yöntem}

\section{Araştırmanın Modeli}

$\mathrm{Bu}$ çalışmada betimsel araştırma modeli kullanılmıştır. Betimsel araştırmalar bir durumun olduğu gibi açıklanması için ayrıntılı bir şekilde incelenmesinde tercih edilen araştırma yöntemleridir (Yıldırım, 2019, s. 94).

\section{Verilerin Toplanmas1}

Çalışma verilerinin toplanması aşamasında dökuman incelemesi yöntemi kullanılmıştır. Doküman incelemesi, araştırılmak istenen konular hakkında bilgi içeren yazılı materyallerin analizidir (Karaman, 2019, s. 37). Önceden resmi veya özel olarak oluşturulan her türlü belge nicel ve nitel araştırmalarda veri kaynağ1 olarak kullanılabilmektedir (Sönmez ve Alacapınar, 2019, s. 188-189). 
Bu kapsamda Türkiye Futbol Federasyonu tarafından her sezon sonu paylaşılan kulüplerin istatistiklerini içeren belgeler çalışmanın temel veri kaynağını oluşturmuştur. Ayrıca çalışma konusuna ilişkin istatistiksel veri tabanlarından da faydalanılmıştır.

\section{Verilerin Analizi}

Çalışma kapsamında 2010-2011 sezonu ile 2019-2020 sezonları arasında süper lig futbol kulüplerinde yer alan Türk Vatandaşı ve yabancı futbolcu sayıları ile müsabakalarda görev alınan toplam süre analiz edilerek frekans ve yüzde değerleri elde edilmiştir. Bunun yanında 2015-2020 sezonları arasında Türk futbol kulüplerinin Avrupa kupaları başarıları sonucunda elde edilen ülke puanı, futbolda yabancı futbolcu sinırlamasının uygulandı̆̆1 2010-2011 sezonu ile 2014-2015 sezonları arasındaki ülke puanı ile karşılaştırılmıştır. Ayrıca Türkiye A milli futbol takımının 2010-2020 yılları arasındaki FIFA başarı sıralamaları da yabancı futbolcu düzenlemeleri ile ilişkisel olarak analiz edilmiştir. FIFA tarafından açıklanan ülke puanları 2006-2018 yılları arasında farkl1, 2018'den sonra farklı puanlama sistemi kullanılması nedeniyle çalışmaya dâhil edilmemiştir. Yabancı futbolcu sınırlamalarının milli takım kadroları üzerinde etkilerinin belirlenmesi amacıyla 2010-2020 y1lları arasındaki kadro analizleri yapılmıştır. Çalışmada Türk Vatandaşı olarak kodlanan futbolcular Türkiye A Milli Futbol takımında yer alabilme niteliğine sahip futbolcuları ifade etmektedir. Türk Vatandaşı olup başka ülke ulusal milli takımında yer alan futbolcular yabancı statüsünde değerlendirilmiştir. İstatistik analizleri için Microsoft Excel programı kullanılmıştır. Çalışmadaki analizler Türkiye Futbol Süper Ligi yabancı futbolcu kısıtlamaları dikkate alınarak yapılmıştır. Yabancı futbolcu düzenlemeleri ile ilgili olmayan, futbol kuralları ve kısıtlamaları yapılan analizlerde dikkate alınmamıştır.

\section{Bulgular}

Tablo 2. Süper lig 2010 Ağustos - 2015 Mayıs Arası Kulüplerin Toplam Futbolcu Sayısı

\begin{tabular}{lcccccc}
\hline \multicolumn{1}{c}{ Kulüp $\boldsymbol{A d} \boldsymbol{1}$} & $\mathbf{2 0 1 0 - 2 0 1 1}$ & $\mathbf{2 0 1 1 - 2 0 1 2}$ & $\mathbf{2 0 1 2 - 2 0 1 3}$ & $\mathbf{2 0 1 3 - 2 0 1 4}$ & $\mathbf{2 0 1 4 - 2 0 1 5}$ & $\begin{array}{c}\text { 2010-2015 } \\
\text { Toplam }\end{array}$ \\
\hline Türk Vatandaşı Futbolcu & 437 & 388 & 421 & 468 & 420 & 2134 \\
Sayıs1 ve Yüzdesi & $(\% 68,06)$ & $(\% 65,98)$ & $(\% 66,71)$ & $(\% 67,14)$ & $(\% 67,41)$ & $\mathbf{( \% 6 7 , 0 8 )}$ \\
Yabanc1 Futbolcu Sayıs1 ve & 205 & 200 & 210 & 229 & 203 & $\mathbf{1 0 4 7}$ \\
Yüzdesi & $(\% 31,93)$ & $(\% 34,01)$ & $(\% 33,28)$ & $(\% 32,85)$ & $(\% 32,58)$ & $\mathbf{( \% 3 2 , 9 1 )}$ \\
Toplam Futbolcu & $\mathbf{6 4 2}$ & $\mathbf{5 8 8}$ & $\mathbf{6 3 1}$ & $\mathbf{6 9 7}$ & $\mathbf{6 2 3}$ & $\mathbf{3 1 8 1}$ \\
\hline
\end{tabular}

Kaynak: Süper Lig Kadro Bilgileri (2010-2015).

2010-2011 sezonunda Türkiye Süper Liginde yer alan toplam 642 futbolcunun \%31,93’ü (205 futbolcu) yabanc1, 2011-2012 sezonunda toplam 588 futbolcunun \%34,01'i (200 futbolcu) yabanc1, 20122013 sezonunda toplam 631 futbolcunun \%33,28’i (210 futbolcu) yabanc1, 2013-2014 sezonunda toplam 697 futbolcunun \%32,85’i (229 futbolcu) yabanc1, 2014-2015 sezonunda toplam 623 futbolcunun \%32,58’i (203 futbolcu) yabancı olmuştur. 2010 A ğustos - 2015 Mayıs arasında toplam futbolcuların \%67,08’i Türk Vatandaşı futbolcuyken, \%32,91’i yabanc1 futbolcu olmuştur.

Tablo 3. Süper Lig 2015 A Ăustos - 2020 Temmuz. Arası Kulüplerin Toplam Futbolcu Sayısı

\begin{tabular}{lcccccc}
\hline \multicolumn{1}{c}{ Kulüp $\boldsymbol{A d \boldsymbol { 1 }}$} & $\mathbf{2 0 1 5 - 2 0 1 6}$ & $\mathbf{2 0 1 6 - 2 0 1 7}$ & $\mathbf{2 0 1 7 - 2 0 1 8}$ & $\mathbf{2 0 1 8 - 2 0 1 9}$ & $\mathbf{2 0 1 9 - 2 0 2 0}$ & $\begin{array}{c}\text { 2015-2020 } \\
\text { Toplam }\end{array}$ \\
\hline Türk Vatandaş1 Futbolcu & 414 & 391 & 346 & 405 & 390 & $\mathbf{1 9 4 6}$ \\
Say1s1 ve Yüzdesi & $(\% 61,69)$ & $(\% 56,66)$ & $(\% 52,58)$ & $(\% 56,17)$ & $(\% 55,55)$ & $\mathbf{( \% 5 6 , 5 3 )}$ \\
Yabanc1 Futbolcu Say1s1 ve & 257 & 299 & 312 & 316 & 312 & $\mathbf{1 4 9 6}$ \\
Yüzdesi & $(\% 38,3)$ & $(\% 43,33)$ & $(\% 47,41)$ & $(\% 43,82)$ & $(\% 44,44)$ & $\mathbf{( \% 4 3 , 4 6 )}$ \\
Toplam Futbolcu & $\mathbf{6 7 1}$ & $\mathbf{6 9 0}$ & $\mathbf{6 5 8}$ & $\mathbf{7 2 1}$ & $\mathbf{7 0 2}$ & $\mathbf{3 4 4 2}$ \\
\hline
\end{tabular}

Kaynak: Süper Lig Kadro Bilgileri (2015-2020).

2015-2016 sezonunda Türkiye Süper Liginde yer alan toplam 671 futbolcunun \%38,3’ü (257 futbolcu) yabanc1, 2016-2017 sezonunda toplam 690 futbolcunun \%43,3’ü (299 futbolcu) yabanc1, 20172018 sezonunda toplam 658 futbolcunun \%47,4’ü (312 futbolcu) yabanc1, 2018-2019 sezonunda toplam 721 futbolcunun \%43,8’i (316 futbolcu) yabanc1, 2019-2020 sezonunda toplam 702 futbolcunun \%44,4’ü (312 futbolcu) yabanci olmuştur. 2015 Ağustos - 2020 Temmuz arasinda toplam futbolcuların \%56,53'ü Türk Vatandaş1 futbolcuyken, \%43,46’s1 yabanc1 futbolcu olmuştur. 
Tablo 4. 2010-2011 Sezonu Müsabakalarda Görev Alan Futbolculara Iliş̧kin Veriler

\begin{tabular}{|c|c|c|c|c|c|c|c|c|}
\hline \multirow{3}{*}{ Lig Siralaması - Kulüp Adı } & \multicolumn{4}{|c|}{ T.C. Vatandaş1 } & \multicolumn{4}{|c|}{ Yabanc1 } \\
\hline & \multicolumn{2}{|c|}{ Futbolcu } & \multicolumn{2}{|c|}{ Görev Süresi } & \multicolumn{2}{|c|}{ Futbolcu } & \multicolumn{2}{|c|}{ Görev Süresi } \\
\hline & Sayisi & Oran1 (\%) & $d k$ & Oran1 (\%) & Sayıs1 & Oran1 (\%) & Sayis1 & Oran1 (\%) \\
\hline 1. Fenerbahçe & 15 & 60 & 16486 & 49,08 & 10 & 40 & 17104 & 50,91 \\
\hline 2. Trabzonspor & 16 & 64 & 21808 & 64,94 & 9 & 36 & 11772 & 35,05 \\
\hline 3. Bursaspor & 16 & 59,25 & 20680 & 63,42 & 11 & 40,74 & 11923 & 36,57 \\
\hline 4. Gaziantepspor & 19 & 65,51 & 18089 & 54,05 & 10 & 34,48 & 15374 & 45,94 \\
\hline 5. Beşiktaş & 22 & 59,45 & 17135 & 52,8 & 15 & 40,54 & 15316 & 50,98 \\
\hline 6. Kayserispor & 17 & 60,71 & 21034 & 62,49 & 11 & 39,28 & 12625 & 37,50 \\
\hline 7. Eskişehirspor & 17 & 62,96 & 21072 & 62,83 & 10 & 37,03 & 12463 & 37,16 \\
\hline 8. Galatasaray & 21 & 63,63 & 19688 & 58,60 & 12 & 36,36 & 13909 & 41,39 \\
\hline 9. Kardemir Karabükspor & 19 & 67,85 & 17965 & 53,41 & 9 & 32,14 & 15670 & 46,58 \\
\hline 10. Manisaspor & 18 & 62,06 & 20291 & 60,54 & 11 & 37,93 & 13225 & 39,45 \\
\hline 11. Medical Park Antalyaspor & 19 & 76 & 25752 & 76,48 & 6 & 24 & 7917 & 23,51 \\
\hline 12. Büyükșehir Bld. Spor & 24 & 77,41 & 25215 & 75,12 & 7 & 22,58 & 8348 & 24,87 \\
\hline 13. MKE Ankaragücü & 23 & 67,64 & 19080 & 56,79 & 11 & 32,35 & 14515 & 43,2 \\
\hline 14. Gençlerbirliği & 21 & 61,76 & 25389 & 75,59 & 13 & 38,23 & 8197 & 24,4 \\
\hline 15. Sivasspor & 19 & 57,57 & 22337 & 66,58 & 14 & 42,42 & 11211 & 33,41 \\
\hline 16. Bucaspor & 28 & 70 & 21285 & 63,71 & 12 & 30 & 12122 & 36,28 \\
\hline 17. Konyaspor & 24 & 60 & 18892 & 56,26 & 16 & 40 & 14682 & 43,73 \\
\hline 18. Kasımpaşa & 21 & 65,62 & 20860 & 62,13 & 11 & 34,37 & 12712 & 37,86 \\
\hline Ortalama & 19,94 & 64,45 & 20725 & 61,95 & 11 & 35,54 & 12726 & 38,04 \\
\hline
\end{tabular}

Kaynak: Süper Lig İstatistikleri (2010-2011)

Tablo 4'te yer alan Süper Lig 2010-2011 Sezonu verilerine göre müsabakalarda yer alan futbolcuların \%64,45’i Türk Vatandaşı, 35,54’ü ise yabanc1 futbolculardır. Müsabakalarda toplam sürenin \% $\% 1,95$ 'inde Türk Vatandaşı, \%38,04'ünde yabanc1 futbolcular görev almıştır. 2010-2011 Sezonunu 1. sırada tamamlayarak Süper Lig şampiyonu olan Fenerbahçe, yürütülen şike soruşturması nedeniyle TFF tarafindan 2011-2012 sezonunda UEFA Şampiyonlar Ligi'nden men edilmiştir (TFF, 2011a). Fenerbahçe'nin yerine ligi ikinci sırada tamamlayan Trabzonspor Şampiyonlar Ligi gruplarına doğrudan katılmıştır (TFF, 2011b). Bursaspor, Gaziantepspor ve Beşiktaş ise UEFA Avrupa Liginde mücadele eden diğer takımlar olmuştur.

Tablo 5. 2011-2012 Sezonu Müsabakalarda Görev Alan Futbolculara Iliş̧kin Veriler

\begin{tabular}{|c|c|c|c|c|c|c|c|c|}
\hline \multirow{3}{*}{ Lig Sıralaması - Kulüp Adı } & \multicolumn{4}{|c|}{ T.C. Vatandaş1 } & \multicolumn{4}{|c|}{ Yabanc1 } \\
\hline & \multicolumn{2}{|c|}{ Futbolcu } & \multicolumn{2}{|c|}{ Görev Süresi } & \multicolumn{2}{|c|}{ Futbolcu } & \multicolumn{2}{|c|}{ Görev Süresi } \\
\hline & Say1s1 & Orani (\%) & $d k$ & Oran1 (\%) & Say1s1 & Oran1 (\%) & Say1s1 & Oran1 (\%) \\
\hline 1. Galatasaray & 20 & 74,07 & 21437 & 53,04 & 7 & 25,92 & 18973 & 46,95 \\
\hline 2. Fenerbahçe & 17 & 65,38 & 20550 & 52,06 & 9 & 34,61 & 18922 & 47,93 \\
\hline 3. Trabzonspor & 11 & 47,82 & 22158 & 56,07 & 12 & 52,17 & 17354 & 43,92 \\
\hline 4. Beşiktaş & 12 & 42,85 & 16240 & 40,13 & 16 & 57,14 & 24223 & 59,86 \\
\hline 5. Eskişehirspor & 15 & 60 & 20381 & 51,72 & 10 & 40 & 19019 & 48,27 \\
\hline 6. İstanbul BBSK & 18 & 64,28 & 21247 & 52,64 & 10 & 35,71 & 19114 & 47,35 \\
\hline 7. Sivasspor & 16 & 55,17 & 20985 & 53,35 & 13 & 44,82 & 18349 & 46,64 \\
\hline 8. Bursaspor & 16 & 59,25 & 20673 & 52,3 & 11 & 40,74 & 18849 & 47,69 \\
\hline 9. Gençlerbirliği & 28 & 77,77 & 28949 & 73,15 & 8 & 22,22 & 10623 & 26,84 \\
\hline 10. Gaziantepspor & 26 & 72,22 & 22550 & 55,60 & 10 & 27,77 & 17947 & 44,31 \\
\hline 11. Kayserispor & 19 & 61,29 & 20537 & 51,96 & 12 & 38,7 & 18983 & 48,03 \\
\hline 12. Kardemir Karabükspor & 30 & 73,17 & 22960 & 56,77 & 11 & 26,82 & 17477 & 43,22 \\
\hline 13. Mersin İdman Yurdu & 15 & 51,72 & 16796 & 50,33 & 14 & 48,27 & 16573 & 49,66 \\
\hline 14. Orduspor & 19 & 63,33 & 22579 & 55,63 & 11 & 36,66 & 18008 & 44,36 \\
\hline 15. Medical Park Antalyaspor & 24 & 80 & 32409 & 82,08 & 6 & 20 & 7073 & 17,91 \\
\hline 16. Samsunspor & 29 & 69,04 & 21013 & 53,16 & 13 & 30,95 & 18510 & 46,83 \\
\hline 17. Manisaspor & 19 & 63,33 & 20903 & 62,62 & 11 & 36,66 & 12473 & 37,37 \\
\hline 18. MKE Ankaragücü & 40 & 90,9 & 36842 & 93,32 & 4 & 9,09 & 2634 & 6,67 \\
\hline Ortalama & 20,77 & 66,54 & 22733 & 58,1 & 10,44 & 33,45 & 16394 & 41,89 \\
\hline
\end{tabular}

Kaynak: Süper Lig İstatistikleri (2011-2012) 
Tablo 5’te yer alan Süper Lig 2011-2012 Sezonu verilerine göre müsabakalarda yer alan futbolcuların $\% 66,54$ 'ü Türk Vatandaşı, 33,45'i ise yabanc1 futbolcular olmuştur. Müsabakalarda toplam sürenin $\% 58,1$ 'inde Türk Vatandaşı futbolcular, \%41,89'unda yabanc1 futbolcular görev almıştır. Play-off uygulamasının denendiği 2011-2012 Sezonunda, Beşiktaş'ın mali kriterleri ve UEFA normlarını karşılayamaması sebebiyle 1 yıl men edilmesi üzerine (Ntv Spor, 2012), 2012-2013 sezonunda Avrupa kupalarına Galatasaray, Fenerbahçe, Trabzonspor, Eskişehirspor ve Bursaspor katılmıştır.

Tablo 6. 2012-2013 Sezonu Müsabakalarda Görev Alan Futbolculara Ilisksin Veriler

\begin{tabular}{|c|c|c|c|c|c|c|c|c|}
\hline \multirow{3}{*}{ Lig Sıralaması - Kulüp Adı } & \multicolumn{4}{|c|}{ T.C. Vatandaş1 } & \multicolumn{4}{|c|}{ Yabanc1 } \\
\hline & \multicolumn{2}{|c|}{ Futbolcu } & \multicolumn{2}{|c|}{ Görev Süresi } & \multicolumn{2}{|c|}{ Futbolcu } & \multicolumn{2}{|c|}{ Görev Süresi } \\
\hline & Say1s1 & Oran1 (\%) & $d k$ & Oran1 (\%) & Say1s1 & Oran1 (\%) & Sayıs & Oran1 (\%) \\
\hline 1. Galatasaray & 17 & 60,71 & 17166 & 51,15 & 11 & 39,28 & 16391 & 48,84 \\
\hline 2. Fenerbahçe & 18 & 62,06 & 19244 & 57,35 & 11 & 37,93 & 14309 & 42,64 \\
\hline 3. Beşiktaş & 18 & 64,28 & 15738 & 46,92 & 10 & 35,71 & 17802 & 53,07 \\
\hline 4. Bursaspor & 21 & 63,63 & 16046 & 47,7 & 12 & 36,36 & 17590 & 52,29 \\
\hline 5. Kayserispor & 15 & 55,55 & 16074 & 48,03 & 12 & 44,44 & 17389 & 51,96 \\
\hline 6. Kasımpaşa & 15 & 55,55 & 19089 & 56,81 & 12 & 44,44 & 14508 & 43,18 \\
\hline 7. Medical Park Antalyaspor & 20 & 74,07 & 23249 & 69,17 & 7 & 25,92 & 10362 & 30,82 \\
\hline 8. Eskişehirspor & 15 & 60 & 14210 & 42,3 & 10 & 40 & 19357 & 57,66 \\
\hline 9. Trabzonspor & 15 & 53,57 & 18354 & 54,6 & 13 & 46,42 & 15258 & 45,39 \\
\hline 10. Gaziantepspor & 17 & 56,66 & 16900 & 50,36 & 13 & 43,33 & 16657 & 49,63 \\
\hline 11. Gençlerbirliği & 18 & 62,06 & 16384 & 48,91 & 11 & 37,93 & 17113 & 51,08 \\
\hline 12. Sivasspor & 17 & 62,96 & 17889 & 53,33 & 10 & 37,03 & 15653 & 46,66 \\
\hline 13. Sanica Boru Elazığspor & 23 & 63,88 & 20638 & 61,52 & 13 & 36,11 & 12905 & 38,47 \\
\hline 14. Akhisar Belediye & 17 & 70,83 & 26799 & 79,57 & 7 & 29,16 & 6879 & 20,42 \\
\hline 15. Kardemir Karabükspor & 21 & 67,74 & 18969 & 56,52 & 10 & 32,25 & 14589 & 43,47 \\
\hline 16. İstanbul BBSK & 16 & 61,53 & 16207 & 48,24 & 10 & 38,46 & 17384 & 51,75 \\
\hline 17. Orduspor & 21 & 67,74 & 17220 & 51,45 & 10 & 32,25 & 16245 & 48,54 \\
\hline 18. Mersin İdman Yurdu & 22 & 57,89 & 15607 & 46,35 & 16 & 42,10 & 18063 & 53,64 \\
\hline Ortalama & 18,11 & 62,21 & 18099 & 53,91 & 11 & 37,78 & 15469 & 46,08 \\
\hline
\end{tabular}

Kaynak: Süper Lig İstatistikleri (2012-2013)

Tablo 6'da yer alan Süper Lig 2012-2013 Sezonu verilerine göre müsabakalarda yer alan futbolcuların $\% 62,21$ ' $\mathrm{i}$ Türk Vatandaşı, 37,78’i ise yabanc1 futbolcular olmuştur. Müsabakalarda toplam sürenin \%53,91'inde Türk Vatandaş1 futbolcular, \%46,08'inde yabancı futbolcular görev almışır. 2013-2014 Sezonunda Avrupa kupalarına Galatasaray, Fenerbahçe, Beşiktaş, Bursaspor ve Türkiye Kupasını kazanan Fenerbahçe Şampiyonlar Ligine katılım hakkı elde ettiği için, kupa finalisti Trabzonspor katılmıştır.

Tablo 7. 2013-2014 Sezonu Müsabakalarda Görev Alan Futbolculara İliskin Veriler

\begin{tabular}{|c|c|c|c|c|c|c|c|c|}
\hline \multirow{3}{*}{ Lig Siralaması - Kulüp Adı } & \multicolumn{4}{|c|}{ T.C. Vatandaş1 } & \multicolumn{4}{|c|}{ Yabanc1 } \\
\hline & \multicolumn{2}{|c|}{ Futbolcu } & \multicolumn{2}{|c|}{ Görev Süresi } & \multicolumn{2}{|c|}{ Futbolcu } & \multicolumn{2}{|c|}{ Görev Süresi } \\
\hline & Say1s1 & Oran1 (\%) & $d k$ & Oran1 (\%) & Say1s1 & Oran1 (\%) & Say1s1 & Oran1 (\%) \\
\hline 1. Fenerbahçe & 16 & 61,53 & 18711 & 55,94 & 10 & 38,46 & 14737 & 44,05 \\
\hline 2. Galatasaray & 20 & 57,14 & 17708 & 52,87 & 15 & 42,85 & 15783 & 47,12 \\
\hline 3. Beşiktaş & 16 & 55,17 & 16437 & 49,03 & 13 & 44,82 & 17083 & 50,96 \\
\hline 4. Trabzonspor & 21 & 67,74 & 19974 & 59,46 & 10 & 32,25 & 13617 & 40,53 \\
\hline 5. Sivasspor & 20 & 66,66 & 20329 & 60,68 & 10 & 33,33 & 13171 & 39,31 \\
\hline 6. Kasımpaşa & 19 & 67,85 & 16433 & 48,9 & 9 & 32,14 & 17166 & 51,09 \\
\hline 7. Kardemir Karabükspor & 16 & 61,53 & 19837 & 59,12 & 10 & 38,46 & 13716 & 40,87 \\
\hline 8. Bursaspor & 19 & 59,37 & 16281 & 48,42 & 13 & 40,62 & 17343 & 51,57 \\
\hline 9. Gençlerbirliği & 15 & 53,57 & 15097 & 44,89 & 13 & 46,42 & 18532 & 55,10 \\
\hline 10. Akhisar Belediye & 21 & 77,77 & 25042 & 74,77 & 6 & 22,22 & 8448 & 25,22 \\
\hline 11. Torku Konyaspor & 17 & 60,71 & 18749 & 55,72 & 11 & 39,28 & 14898 & 44,27 \\
\hline 12. Eskişehirspor & 19 & 61,29 & 16048 & 47,75 & 12 & 38,70 & 17557 & 52,24 \\
\hline 13. Çaykur Rizespor & 18 & 60 & 18140 & 53,89 & 12 & 40 & 15520 & 46,10 \\
\hline 14. Kayseri Erciyesspor & 20 & 62,5 & 16223 & 48,31 & 12 & 37,5 & 17353 & 51,68 \\
\hline 15. Gaziantepspor & 18 & 60 & 17236 & 51,37 & 12 & 40 & 16314 & 48,62 \\
\hline 16. Elazığspor & 23 & 60,52 & 17503 & 52,13 & 15 & 39,47 & 16070 & 47,86 \\
\hline 17. Medical Park Antalyaspor & 22 & 68,75 & 25306 & 75,26 & 10 & 31,25 & 8315 & 24,73 \\
\hline 18. Kayserispor & 15 & 51,72 & 15832 & 47,17 & 14 & 48,27 & 17725 & 52,82 \\
\hline Ortalama & 18,61 & 61,8 & 18382 & 54,76 & 11,5 & 38,19 & 15186 & 45,23 \\
\hline
\end{tabular}

Kaynak: Süper Lig İstatistikleri (2013-2014) 
Tablo 7'de yer alan Süper Lig 2013-2014 Sezonu verilerine göre müsabakalarda yer alan futbolcularnn $\% 61,8$ 'i Türk Vatandaşı, 38,19'u ise yabanc1 futbolcular olmuştur. Müsabakalarda toplam sürenin \%54,76'sında Türk Vatandaşı futbolcular, \%45,23'ünda yabanc1 futbolcular görev almıştır. Fenerbahçe UEFA'nın vermiş olduğu iki yıl Avrupa kupalarından men kararı nedeniyle 2014-2015 sezonunda Şampiyonlar Ligi'ne katılamamıstır. Fenerbahçe yerine lig ikincisi Galatasaray Şampiyonlar Ligi gruplarına direkt katılmıştır. Ligi beşinci sırada bitiren Sivasspor ve Türkiye Kupası finalisti olarak Avrupa Ligine katılma hakkı kazanan Eskişehirspora şike davası sebebiyle UEFA'nın birer yıllık men cezası vermesi ve ligi altıncı sırada bitirmiş olan Kasımpaşa'nın UEFA kulüp lisansı alamaması üzerine (Ntv Spor, 2014), Avrupa kupalarına katılan diğer takımlar Beşiktaş, Trabzonspor, Kardemir Karabükspor ve Bursaspor olmuştur.

Tablo 8. 2014-2015 Sezonu Müsabakalarda Görev Alan Futbolculara İliskin Veriler

\begin{tabular}{|c|c|c|c|c|c|c|c|c|}
\hline \multirow{3}{*}{ Lig Siralaması - Kulüp Adı } & \multicolumn{4}{|c|}{ T.C. Vatandaşı } & \multicolumn{4}{|c|}{ Yabanc1 } \\
\hline & \multicolumn{2}{|c|}{ Futbolcu } & \multicolumn{2}{|c|}{ Görev Süresi } & \multicolumn{2}{|c|}{ Futbolcu } & \multicolumn{2}{|c|}{ Görev Süresi } \\
\hline & Say1s1 & Oran1 (\%) & $d k$ & Oran1 (\%) & Sayıs1 & Oran1 (\%) & Sayıs1 & Oran1 (\%) \\
\hline 1. Galatasaray & 16 & 59,25 & 19691 & 58,51 & 11 & 40,74 & 13960 & 41,48 \\
\hline 2. Fenerbahçe & 14 & 63,63 & 20113 & 59,88 & 8 & 36,36 & 13473 & 40,11 \\
\hline 3. Beşiktaş & 15 & 60 & 18333 & 54,69 & 10 & 40 & 15186 & 45,30 \\
\hline 4. İstanbul Başakşehir & 17 & 68 & 19840 & 59,17 & 8 & 32 & 13689 & 40,82 \\
\hline 5. Trabzonspor & 23 & 69,69 & 20690 & 61,46 & 10 & 30,3 & 12970 & 38,53 \\
\hline 6. Bursaspor & 15 & 65,21 & 17858 & 53,31 & 8 & 34,78 & 15636 & 46,68 \\
\hline 7. Mersin İdmanyurdu & 18 & 69,23 & 19561 & 58,31 & 8 & 30,76 & 13983 & 41,68 \\
\hline 8. Torku Konyaspor & 16 & 61,53 & 20848 & 62,04 & 10 & 38,46 & 12755 & 37,95 \\
\hline 9. Gençlerbirliği & 19 & 61,29 & 18207 & 54,22 & 12 & 38,70 & 15371 & 45,77 \\
\hline 10. Gaziantepspor & 17 & 56,66 & 19288 & 57,5 & 13 & 43,33 & 14254 & 42,49 \\
\hline 11. Eskişehirspor & 24 & 75 & 19328 & 57,53 & 8 & 25 & 14265 & 42,46 \\
\hline 12. Akhisar Belediye & 22 & 68,75 & 20504 & 61,24 & 10 & 31,25 & 12976 & 38,75 \\
\hline 13. Kasımpaşa & 19 & 65,51 & 17814 & 53,16 & 10 & 34,48 & 15691 & 46,83 \\
\hline 14. Çaykur Rizespor & 16 & 59,25 & 19912 & 59,43 & 11 & 40,74 & 13591 & 40,56 \\
\hline 15. Medicana Sivasspor & 19 & 70,37 & 21821 & 64,92 & 8 & 29,62 & 11787 & 35,07 \\
\hline 16. Kardemir Karabükspor & 19 & 65,51 & 18623 & 55,53 & 10 & 34,48 & 14908 & 44,46 \\
\hline 17. Suat Altın İnş. Kayseri Erciyesspor & 21 & 63,63 & 17943 & 54,46 & 12 & 36,36 & 15620 & 46,53 \\
\hline 18. Balıkesirspor & 19 & 63,33 & 21543 & 64,2 & 11 & 36,66 & 12013 & 35,79 \\
\hline Ortalama & 18,27 & 64,89 & 19550 & 58,26 & 9,88 & 35,1 & 14007 & 41,73 \\
\hline
\end{tabular}

Kaynak: Süper Lig İstatistikleri (2014-2015)

Tablo 8'de yer alan Süper Lig 2014-2015 Sezonu verilerine göre müsabakalarda yer alan futbolcularnn $\%$ 64,89'u Türk Vatandaşı, 35,1'i ise yabanc1 futbolcular olmuştur. Müsabakalarda toplam sürenin \%58,26'sında Türk Vatandaşı, \%41,93'ünde yabancı futbolcular görev almıştır. 2015-2016 Sezonunda ilk beş takım Avrupa kupalarında mücadele hakkı kazanmışır.

Tablo 9. 2015-2016 Sezonu Müsabakalarda Görev Alan Futbolculara Ilisskin Veriler

\begin{tabular}{|c|c|c|c|c|c|c|c|c|}
\hline \multirow{3}{*}{ Lig S1ralamas1 - Kulüp Ad1 } & \multicolumn{4}{|c|}{ T.C. Vatandaşı } & \multicolumn{4}{|c|}{ Yabanc1 } \\
\hline & \multicolumn{2}{|c|}{ Futbolcu } & \multicolumn{2}{|c|}{ Görev Süresi } & \multicolumn{2}{|c|}{ Futbolcu } & \multicolumn{2}{|c|}{ Görev Süresi } \\
\hline & Say1s1 & Oran1 (\%) & $d k$ & Oran1 (\%) & Say1s1 & Oran1 (\%) & Say1s1 & Oran1 (\%) \\
\hline 1. Beşiktaş & 12 & 48 & 15383 & 45,72 & 13 & 52 & 18259 & 54,27 \\
\hline 2. Fenerbahçe & 13 & 50 & 15759 & 46,9 & 13 & 50 & 17841 & 53,09 \\
\hline 3. Torku Konyaspor & 15 & 53,57 & 16474 & 48,98 & 13 & 46,42 & 17159 & 51,01 \\
\hline 4. Medipol Başakşehir & 16 & 66,66 & 21893 & 65,16 & 8 & 33,33 & 11704 & 34,83 \\
\hline 5. Osmalispor & 13 & 44,82 & 16409 & 48,9 & 16 & 55,17 & 17141 & 51,09 \\
\hline 6. Galatasaray & 15 & 55,55 & 18612 & 55,42 & 12 & 44,44 & 14967 & 44,57 \\
\hline 7. Kasımpaşa & 10 & 41,66 & 10847 & 32,34 & 14 & 58,33 & 22691 & 67,65 \\
\hline 8. Akhisar Belediye & 18 & 62,06 & 17232 & 51,32 & 11 & 37,93 & 16341 & 48,67 \\
\hline 9. Antalyaspor & 22 & 56,41 & 12762 & 38,05 & 17 & 43,58 & 20778 & 61,94 \\
\hline 10. Gençlerbirliği & 15 & 51,72 & 14207 & 42,2 & 14 & 48,27 & 19456 & 57,79 \\
\hline 11. Bursaspor & 18 & 52,94 & 12403 & 36,99 & 16 & 47,05 & 21125 & 63 \\
\hline 12. Trabzonspor & 25 & 65,78 & 18861 & 56,36 & 13 & 34,21 & 14603 & 43,63 \\
\hline 13. Çaykur Rizespor & 12 & 52,17 & 17654 & 52,78 & 11 & 43,47 & 15929 & 47,62 \\
\hline 14. Gaziantepspor & 19 & 59,37 & 15812 & 47,19 & 13 & 40,62 & 17690 & 52,8 \\
\hline 15. Kayserispor & 15 & 55,55 & 17819 & 53,26 & 12 & 44,44 & 15637 & 46,73 \\
\hline 16. Medicana Sivasspor & 18 & 58,06 & 15811 & 47,26 & 13 & 41,93 & 17641 & 52,73 \\
\hline 17. Eskişehirspor & 18 & 50 & 18325 & 54,73 & 18 & 50 & 15155 & 45,26 \\
\hline 18. Mersin İdmanyurdu & 24 & 72,72 & 20876 & 62,22 & 9 & 27,27 & 12672 & 37,77 \\
\hline Ortalama & 16,55 & 55,8 & 16507 & 49,2 & 13,11 & 44,19 & 17043 & 50,79 \\
\hline
\end{tabular}

Kaynak: Süper Lig İstatistikleri (2015-2016) 
Tablo 9'da yer alan Süper Lig 2015-2016 Sezonu verilerine göre müsabakalarda yer alan futbolcuların $\% 55,8$ ' i Türk Vatandaşı, 44,19'u ise yabanc1 futbolcular olmuştur. Müsabakalarda toplam sürenin $\% 49,2$ 'sinde Türk Vatandaşı futbolcular, \%50,79’unde yabancı futbolcular görev almıştır. Türkiye kupasını kazanarak Avrupa kupalarına katılma hakkı elde eden Galatasaray Finansal Fair Play kuralları gereği 1 yıl men cezası aldığı için bir sonraki sezon UEFA Avrupa Ligi'ne katılamamıştır (UEFA, 2016). Dolayısıyla İlk 5 takım 2016-2017 Sezonunda Avrupa Kupalarına katılma hakk1 elde etmiştir.

Tablo 10. 2016-2017 Sezonu müsabakalarda görev alan futbolculara iliskin veriler

\begin{tabular}{|c|c|c|c|c|c|c|c|c|}
\hline \multirow{3}{*}{ Lig Siralaması - Kulüp Adı } & \multicolumn{4}{|c|}{ T.C. Vatandaş1 } & \multicolumn{4}{|c|}{ Yabanc1 } \\
\hline & \multicolumn{2}{|c|}{ Futbolcu } & \multicolumn{2}{|c|}{ Görev Süresi } & \multicolumn{2}{|c|}{ Futbolcu } & \multicolumn{2}{|c|}{ Görev Süresi } \\
\hline & Say1s1 & Oran1 (\%) & $d k$ & Oran1 (\%) & Say1s1 & Oran1 (\%) & Sayı1s1 & Oran1 (\%) \\
\hline 1. Beşiktaş & 10 & 38,46 & 10094 & 30,01 & 16 & 61,53 & 23532 & 69,98 \\
\hline 2. Medipol Başakşehir & 16 & 59,25 & 20948 & 62,41 & 11 & 40,74 & 12613 & 37,58 \\
\hline 3. Fenerbahçe & 11 & 44 & 15334 & 45,64 & 14 & 56 & 18262 & 54,35 \\
\hline 4. Galatasaray & 10 & 45,45 & 14547 & 43,27 & 12 & 54,54 & 19071 & 56,72 \\
\hline 5. Antalyaspor & 14 & 45,16 & 12316 & 36,82 & 17 & 54,83 & 21127 & 63,17 \\
\hline 6. Trabzonspor & 14 & 50 & 17611 & 52,54 & 14 & 50 & 15906 & 47,45 \\
\hline 7. Akhisar Belediye & 17 & 53,12 & 19202 & 57,08 & 15 & 46,87 & 14435 & 42,91 \\
\hline 8. Gençlerbirliği & 14 & 45,16 & 17006 & 50,63 & 17 & 54,83 & 16580 & 49,36 \\
\hline 9. Atiker Konyaspor & 13 & 52 & 15056 & 44,81 & 12 & 48 & 18538 & 55,18 \\
\hline 10. Kasımpaşa & 11 & 45,83 & 13027 & 38,72 & 13 & 54,16 & 20610 & 61,27 \\
\hline 11. Kardemir Karabükspor & 13 & 40,62 & 11083 & 33,14 & 19 & 59,37 & 22355 & 66,85 \\
\hline 12. Aytemiz Alanyaspor & 12 & 37,5 & 10981 & 32,68 & 20 & 62,5 & 22613 & 67,31 \\
\hline 13. Osmalispor & 11 & 39,28 & 10296 & 30,59 & 17 & 60,71 & 23362 & 69,4 \\
\hline 14. Bursaspor & 15 & 57,69 & 16905 & 50,59 & 11 & 42,3 & 16508 & 49,4 \\
\hline 15. Kayserispor & 16 & 48,48 & 13510 & 40,25 & 17 & 51,51 & 20053 & 59,74 \\
\hline 16. Çaykur Rizespor & 11 & 42,3 & 13169 & 39,55 & 15 & 57,69 & 20126 & 60,44 \\
\hline 17. Gaziantepspor & 16 & 45,71 & 13798 & 41,15 & 19 & 54,28 & 19732 & 58,84 \\
\hline 18. Adanaspor & 14 & 50 & 9539 & 28,39 & 14 & 50 & 24052 & 71,6 \\
\hline Ortalama & 13,22 & 46,57 & 14134 & 42,13 & 15,16 & 53,42 & 19415 & 57,86 \\
\hline
\end{tabular}

Kaynak: Süper Lig İstatistikleri (2016-2017)

Tablo 10'da yer alan Süper Lig 2016-2017 Sezonu verilerine göre müsabakalarda yer alan futbolcuların \%46,57'si Türk Vatandaşı, 53,42'si ise yabancı futbolcular olmuştur. Müsabakalarda toplam sürenin \%42,13'ünde Türk Vatandaşı futbolcular, \%57,86'sınde yabanc1 futbolcular görev almıştır. 20172018 Sezonunda ilk 4 takım ile birlikte Türkiye kupasını kazanan Atiker Konyaspor Avrupa Kupalarına katılma hakkı elde eden 5. takım olmuştur.

Tablo 11. 2017-2018 Sezonu Müsabakalarda Görev Alan Futbolculara İlişkin Veriler

\begin{tabular}{|c|c|c|c|c|c|c|c|c|}
\hline \multirow{3}{*}{ Lig Siralaması - Kulüp Adı } & \multicolumn{4}{|c|}{ T.C. Vatandaş1 } & \multicolumn{4}{|c|}{ Yabanc1 } \\
\hline & \multicolumn{2}{|c|}{ Futbolcu } & \multicolumn{2}{|c|}{ Görev Süresi } & \multicolumn{2}{|c|}{ Futbolcu } & \multicolumn{2}{|c|}{ Görev Süresi } \\
\hline & Say1s1 & Oran1 (\%) & $d k$ & Oran1 (\%) & Sayı1s & Oran1 (\%) & Say1s1 & Oran1 (\%) \\
\hline 1. Galatasaray & 6 & 17,18 & 5769 & 18,94 & 17 & 73,91 & 27804 & 82,81 \\
\hline 2. Fenerbahçe & 11 & 42,3 & 11494 & 34,2 & 15 & 57,69 & 22106 & 65,79 \\
\hline 3. Medipol Başakşehir & 12 & 46,15 & 11364 & 33,86 & 14 & 53,84 & 22196 & 66,13 \\
\hline 4. Beşiktaş & 8 & 32 & 6787 & 20,26 & 17 & 68 & 26711 & 79,73 \\
\hline 5. Trabzonspor & 14 & 50 & 17079 & 50,92 & 14 & 50 & 16459 & 49,07 \\
\hline 6. Göztepe & 10 & 37,03 & 8027 & 23,91 & 17 & 62,96 & 25534 & 76,08 \\
\hline 7. Demir Grup Sivasspor & 12 & 42,85 & 12201 & 36,41 & 16 & 57,14 & 21307 & 63,58 \\
\hline 8. Kasımpaşa & 8 & 34,78 & 6872 & 20,49 & 15 & 65,21 & 26653 & 79,5 \\
\hline 9. Kayserispor & 9 & 34,61 & 12104 & 36,03 & 17 & 65,38 & 21487 & 63,96 \\
\hline 10. Evkur Yeni Malatyaspor & 13 & 48,14 & 15487 & 46,06 & 14 & 51,85 & 18135 & 53,93 \\
\hline 11. Teleset Mobilya Akhisar & 15 & 55,55 & 17579 & 52,47 & 12 & 44,44 & 15921 & 47,52 \\
\hline 12. Aytemiz Alanyaspor & 9 & 34,61 & 11353 & 33,76 & 17 & 65,38 & 22266 & 66,23 \\
\hline 13. Bursaspor & 16 & 45,71 & 10514 & 31,32 & 19 & 54,28 & 23053 & 68,67 \\
\hline 14. Antalyaspor & 13 & 44,82 & 12463 & 37,15 & 16 & 55,17 & 21076 & 62,84 \\
\hline 15. Atiker Konyaspor & 12 & 40 & 14493 & 43,2 & 18 & 60 & 19054 & 56,79 \\
\hline 16. Osmalispor & 19 & 52,77 & 14895 & 44,25 & 17 & 47,22 & 18766 & 55,74 \\
\hline 17. Gençlerbirliği & 14 & 45,16 & 11200 & 33,46 & 17 & 54,83 & 22267 & 66,53 \\
\hline 18. Kardemir Karabükspor & 20 & 51,28 & 14251 & 42,39 & 19 & 48,71 & 19362 & 57,6 \\
\hline Ortalama & 12,27 & 43,16 & 11885 & 35,41 & 16,16 & 56,83 & 21675 & 64,58 \\
\hline
\end{tabular}

Kaynak: Süper Lig İstatistikleri (2017-2018) 
Tablo 11'de yer alan Süper Lig 2017-2018 Sezonu verilerine göre müsabakalarda yer alan futbolcuların \%43,16'sı Türk Vatandaş1, 56,83'ü ise yabanc1 futbolcular olmuştur. Müsabakalarda toplam sürenin \%35,41'inde Türk Vatandaş1 futbolcular, \%64,58'inde yabanc1 futbolcular görev almıştır. 20182019 Sezonunda ilk 4 takım ile birlikte Türkiye kupasını kazanan Akhisarspor Avrupa Kupalarına katılma hakk1 elde eden 5. takım olmuştur.

Tablo 12. 2018-2019 Sęৃonu Müsabakalarda Görev Alan Futbolculara İliskin Veriler

\begin{tabular}{|c|c|c|c|c|c|c|c|c|}
\hline \multirow{3}{*}{ Lig Sıralaması - Kulüp Adı } & \multicolumn{4}{|c|}{ T.C. Vatandaş1 } & \multicolumn{4}{|c|}{ Yabanc1 } \\
\hline & \multicolumn{2}{|c|}{ Futbolcu } & \multicolumn{2}{|c|}{ Görev Süresi } & \multicolumn{2}{|c|}{ Futbolcu } & \multicolumn{2}{|c|}{ Görev Süresi } \\
\hline & Say1s1 & Oran1 (\%) & $d k$ & Oran1 (\%) & Say1s1 & Oran1 (\%) & Say1s1 & Oran1 (\%) \\
\hline 1. Galatasaray & 14 & 46,87 & 7314 & 21,76 & 18 & 56,25 & 26283 & 78,23 \\
\hline 2. Medipol Başakşehir & 9 & 34,61 & 12066 & 35,84 & 17 & 65,38 & 21594 & 64,15 \\
\hline 3. Beşiktaş & 13 & 43,33 & 11406 & 33,95 & 17 & 56,66 & 22184 & 66,04 \\
\hline 4. Trabzonspor & 15 & 55,55 & 13752 & 40,85 & 12 & 44,44 & 19908 & 59,14 \\
\hline 5. Evkur Yeni Malatyaspor & 15 & 51,72 & 13448 & 40,23 & 14 & 48,27 & 19977 & 59,76 \\
\hline 6. Fenerbahçe & 13 & 40,62 & 12205 & 36,39 & 19 & 59,37 & 21333 & 63,6 \\
\hline 7. Antalyaspor & 15 & 51,72 & 14614 & 43,66 & 14 & 48,27 & 18856 & 56,33 \\
\hline 8. Atiker Konyaspor & 11 & 42,3 & 12764 & 38,02 & 15 & 57,69 & 20800 & 61,97 \\
\hline 9. Aytemiz Alanyaspor & 13 & 44,82 & 12380 & 36,96 & 16 & 55,17 & 21114 & 63,03 \\
\hline 10. İstikbal Mobilya Kayserispor & 14 & 53,84 & 12146 & 36,32 & 12 & 46,15 & 21291 & 63,67 \\
\hline 11. Çaykur Rizespor & 11 & 35,48 & 10541 & 31,54 & 20 & 64,51 & 22876 & 68,45 \\
\hline 12. Demir Grup Sivasspor & 13 & 52 & 15033 & 44,72 & 12 & 48 & 18582 & 55,27 \\
\hline 13. MKE Ankaragücü & 13 & 34,21 & 11757 & 35,07 & 25 & 65,78 & 21762 & 64,92 \\
\hline 14. Kasımpaşa & 11 & 40,74 & 8700 & 25,92 & 16 & 59,25 & 24864 & 74,07 \\
\hline 15. Göztepe & 10 & 40 & 10964 & 32,75 & 15 & 60 & 22512 & 67,24 \\
\hline 16. Bursaspor & 17 & 54,83 & 19335 & 57,44 & 14 & 45,16 & 14321 & 42,55 \\
\hline 17. B.B. Erzurumspor & 14 & 46,66 & 15139 & 45,01 & 16 & 53,33 & 18490 & 54,98 \\
\hline 18. Akhisarspor & 16 & 50 & 14810 & 44,14 & 16 & 50 & 18735 & 55,85 \\
\hline Ortalama & 13,16 & 45,14 & 12687 & 37,81 & 16 & 54,85 & 20860 & 62,18 \\
\hline
\end{tabular}

Kaynak: Süper Lig İstatistikleri (2018-2019)

Tablo 12'de yer alan Süper Lig 2018-2019 Sezonu verilerine göre müsabakalarda yer alan futbolcuların \%45,14'ü Türk Vatandaş1, 54,85'i ise yabancı futbolcular olmuştur. Müsabakalarda toplam sürenin \%37,81'inde Türk Vatandaş1 futbolcular, \%62,18’inde yabanc1 futbolcular görev almıştır. 20192020 Sezonunda ilk 5 takım Avrupa Kupalarına katılma hakkı elde etmiştir.

Tablo 13. 2019-2020 Sez̧onu Müsabakalarda Görev Alan Futbolculara İlişkin Veriler

\begin{tabular}{|c|c|c|c|c|c|c|c|c|}
\hline \multirow{3}{*}{ Lig Sıralaması - Kulüp Adı } & \multicolumn{4}{|c|}{ T.C. Vatandaş1 } & \multicolumn{4}{|c|}{ Yabanc1 } \\
\hline & \multicolumn{2}{|c|}{ Futbolcu } & \multicolumn{2}{|c|}{ Görev Süresi } & \multicolumn{2}{|c|}{ Futbolcu } & \multicolumn{2}{|c|}{ Görev Süresi } \\
\hline & Say1s1 & Oran1 (\%) & $d k$ & Oran1 (\%) & Say1s1 & Oran1 (\%) & Say1s1 & Oran1 (\%) \\
\hline 1. Medipol Başakşehir & 11 & 37,93 & 9412 & 27,99 & 18 & 62,06 & 24213 & 72 \\
\hline 2. Trabzonspor & 15 & 50 & 10930 & 32,59 & 15 & 50 & 22605 & 67,4 \\
\hline 3. Beșiktaş & 15 & 48,38 & 11318 & 33,72 & 16 & 51,61 & 22243 & 66,27 \\
\hline 4. Demir Grup Sivasspor & 13 & 48,14 & 17615 & 52,43 & 14 & 51,85 & 15976 & 47,56 \\
\hline 5. Aytemiz Alanyaspor & 11 & 44 & 7589 & 22,57 & 14 & 56 & 26024 & 77,42 \\
\hline 6. Galatasaray & 12 & 37,5 & 7802 & 23,29 & 20 & 62,5 & 25696 & 76,7 \\
\hline 7. Fenerbahçe & 17 & 53,12 & 14955 & 44,71 & 15 & 46,87 & 18490 & 55,28 \\
\hline 8. Gaziantep Futbol Kulübü & 11 & 42,3 & 10693 & 31,89 & 15 & 57,69 & 22833 & 68,1 \\
\hline 9. Fraport-TAV Antalyaspor & 16 & 50 & 12932 & 38,58 & 16 & 50 & 20583 & 61,41 \\
\hline 10. Kasımpaşa & 13 & 39,39 & 11798 & 35,25 & 20 & 60,6 & 21669 & 64,74 \\
\hline 11. Göztepe & 15 & 50 & 13980 & 41,6 & 15 & 50 & 19619 & 58,39 \\
\hline 12. Gençlerbirliği & 15 & 50 & 10378 & 31,1 & 15 & 50 & 22982 & 68,89 \\
\hline 13. İttifak Holding Konyaspor & 12 & 44,44 & 12206 & 36,5 & 15 & 55,55 & 21231 & 63,49 \\
\hline 14. Yukatel Denizlispor & 12 & 46,15 & 11408 & 34,03 & 14 & 53,84 & 22109 & 65,96 \\
\hline 15. Çaykur Rizespor & 11 & 35,48 & 8500 & 25,31 & 20 & 64,51 & 25077 & 74,68 \\
\hline 16. BTC Türk Yeni Malatyaspor & 11 & 40,74 & 10122 & 30,24 & 16 & 59,25 & 23341 & 69,75 \\
\hline 17. Hes Kablo Kayserispor & 22 & 52,38 & 9785 & 29,18 & 19 & 45,23 & 23743 & 70,81 \\
\hline 18. MKE Ankaragücü & 17 & 50 & 9804 & 29,29 & 17 & 50 & 23659 & 70,7 \\
\hline Ortalama & 13,83 & 45,85 & 11179 & 33,35 & 16,33 & 54,14 & 22338 & 66,64 \\
\hline
\end{tabular}

Kaynak: Süper Lig İstatistikleri (2019-2020)

Tablo 13’te yer alan Süper Lig 2019-2020 Sezonu verilerine göre müsabakalarda yer alan futbolcularnn \%45,85’i Türk Vatandaşı, 54,14’ü ise yabancı futbolcular olmuştur. Müsabakalarda toplam sürenin 
\%33,35’inde Türk Vatandaşı futbolcular, \%66,64’ünde yabanc1 futbolcular görev almıştır. Trabzonspor'un, Avrupa kupalarından 1 yıl men edilmesi nedeniyle (Ntv Spor, 2020), Medipol Başakşehir, Beşiktaş, Sivasspor, Alanyaspor ve ligi 6. olarak tamamlayan Galatasaray da 2020-2021 Sezonunda Avrupa Kupalarına katılma hakkı elde etmiştir.

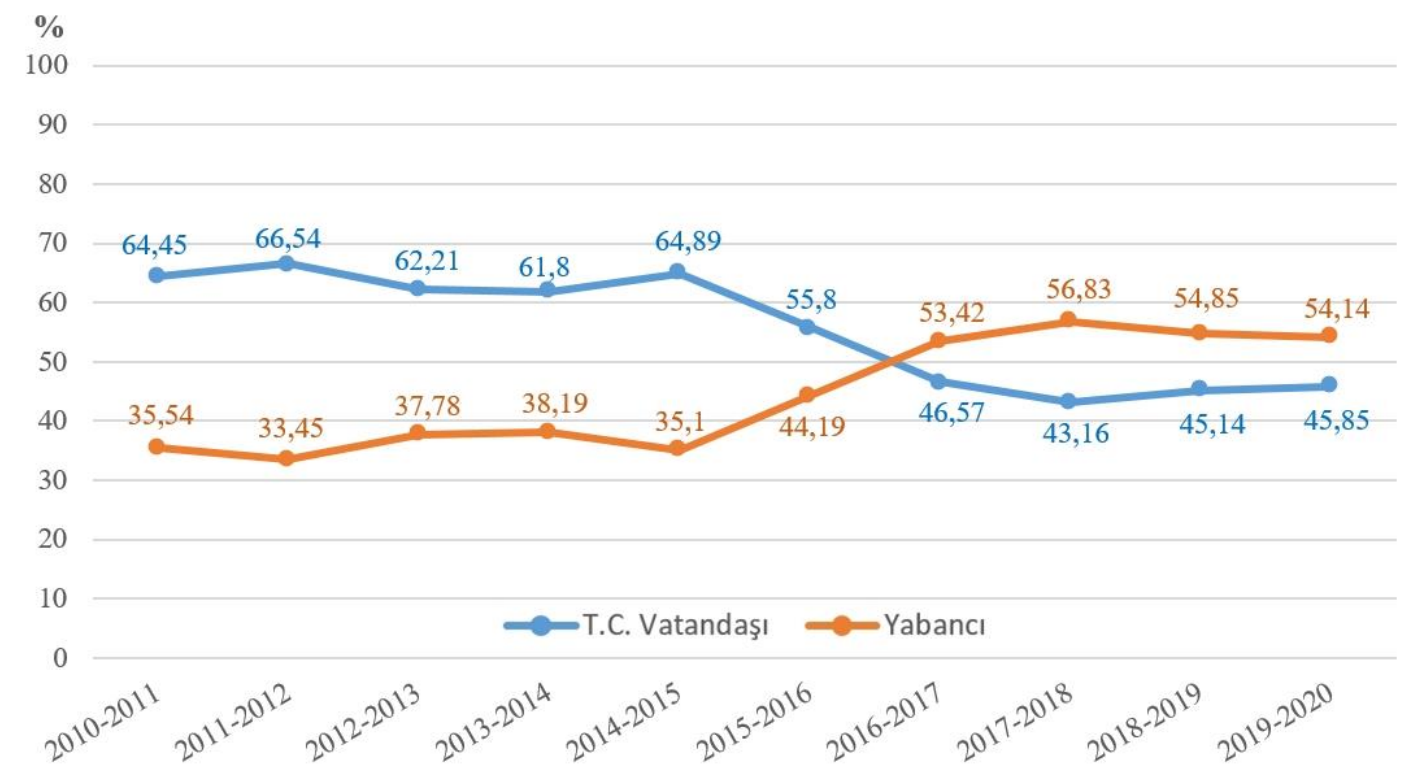

Grafik 1. 2010-2020 Yillar Arası Müsabakalarda Görev Alan Futbolcu Oranlar

Grafik 1 incelendiğinde 2016-2017 sezonundan itibaren müsabakalarda görev alan yabanc1 futbolcu oranlarındaki artış göze çarpmaktadır. 2010-2015 sezonları arası müsabakalarda görev alan Türk Vatandaş1 futbolcularin ortalama oran1 \%64 iken bu oran 2015-2020 sezonlar1 arasinda \%47,35 olmuştur. 2010-2015 sezonları arası müsabakalarda görev alan yabanc1 futbolcuların ortalama oran1 \%35,99 iken bu oran 20152020 sezonları arasinda \%52,64 olmuştur.

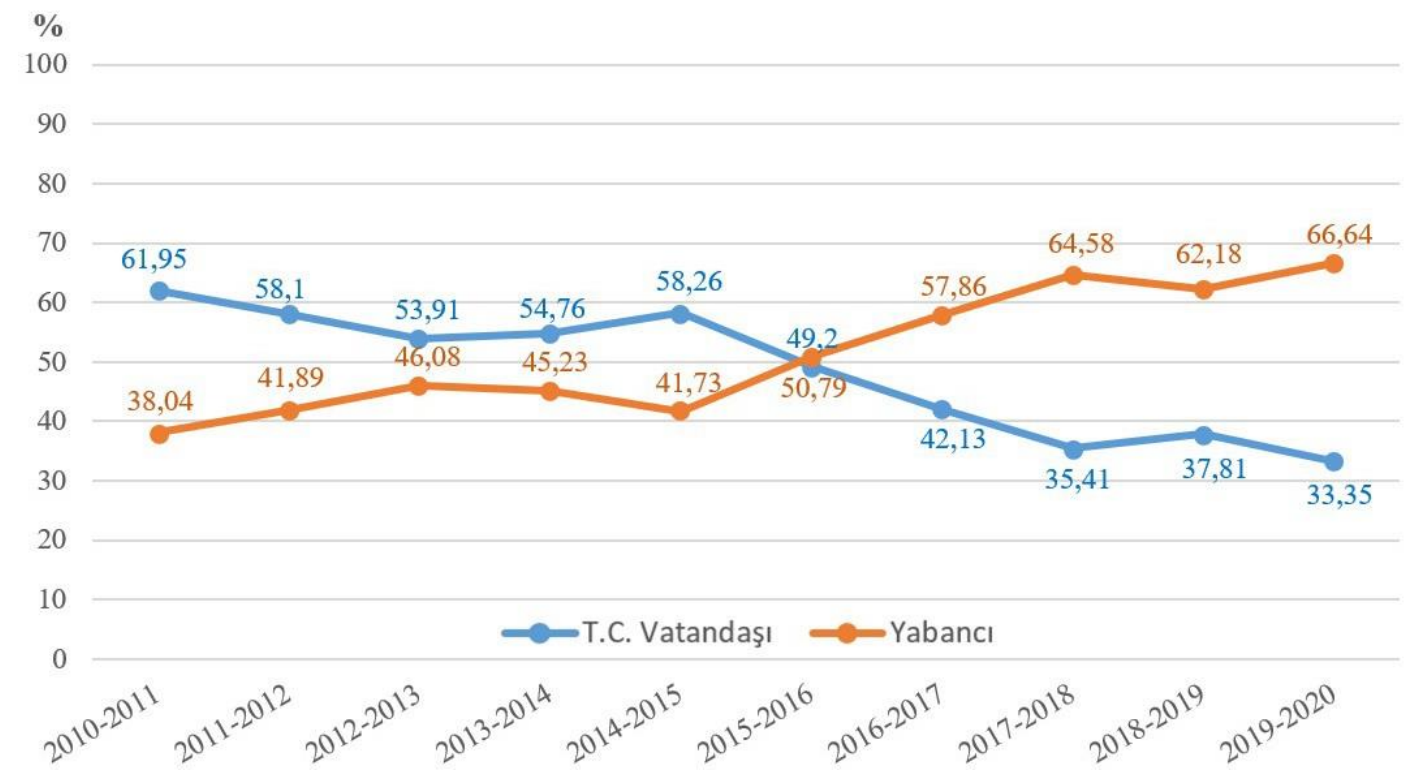

Grafik 2. 2010-2020 Yillar Arası Müsabakalarda Alınan Görev Süresi Oranları

Grafik 2 incelendiğinde 2016-2017 sezonundan itibaren müsabakalarda yabanc1 futbolcuların müsabakalardaki görev süresi oranlarındaki artı̧ göze çarpmaktadır. 2010-2015 sezonlar1 arası müsabakalarda Türk Vatandaşı futbolcuların ortalama görev süresi oranı \%57,41 iken bu oran 2015-2020 sezonlar1 arasında \%39,58 olmuştur. 2010-2015 sezonlar1 aras1 yabanc1 futbolcuların ortalama görev süresi oranı \%42,58 iken bu oran 2015-2020 sezonları arasında \%60,41 olmuştur. 
Tablo 14. 2010 A ğustos-2015 Mayıs Arası UEFA Takım Siralamalar ve Toplanan Puanlar

\begin{tabular}{|c|c|c|c|c|c|c|c|}
\hline \multicolumn{2}{|c|}{ Kulüp Adı } & \multirow{2}{*}{$\frac{2010-2011}{45}$} & \multirow{2}{*}{$\frac{2011-2012}{60}$} & \multirow{2}{*}{$\frac{2012-2013}{41}$} & \multirow{2}{*}{$\frac{2013-2014}{36}$} & \multirow{2}{*}{$\frac{2014-2015}{38}$} & \multirow{2}{*}{$\begin{array}{c}\text { 2010-2015 } \\
\text { Ortalama } \\
44\end{array}$} \\
\hline & Sira & & & & & & \\
\hline Galatasaray & Puan & 1,5 & - & 22 & 15 & 5 & 43,5 \\
\hline \multirow{2}{*}{ Trabzonspor } & Sira & 137 & 97 & 93 & 74 & 59 & 92 \\
\hline & Puan & 1,5 & 10 & 1,5 & 10 & 7 & 30 \\
\hline \multirow{2}{*}{ Fenerbahçe } & Sira & 41 & 53 & 47 & 53 & 75 & 53,8 \\
\hline & Puan & 1,5 & - & 22 & 0 & - & 23,5 \\
\hline \multirow{2}{*}{ Beşiktaş } & Sira & 57 & 52 & 66 & 66 & 58 & 59,8 \\
\hline & Puan & 9 & 10 & - & 0 & 11 & 20 \\
\hline \multirow{2}{*}{ Bursaspor } & Sira & 136 & 124 & 120 & 122 & 119 & 124,2 \\
\hline & Puan & 5 & 1,5 & 1,5 & 1,5 & 0,5 & 10 \\
\hline \multirow{2}{*}{$\begin{array}{l}\text { Kardemir } \\
\text { Karabükspor }\end{array}$} & Sira & - & - & - & - & 199 & - \\
\hline & Puan & - & - & - & - & 1,5 & 1,5 \\
\hline \multirow{2}{*}{ Gaziantepspor } & Sira & - & 176 & 179 & 200 & - & - \\
\hline & Puan & - & 1 & - & - & - & 1 \\
\hline \multirow{2}{*}{ Eskişehirspor } & Sira & - & - & 178 & 199 & - & - \\
\hline & Puan & - & - & 1 & - & - & 1 \\
\hline \multirow{2}{*}{$\begin{array}{l}\text { Türkiye Ülke } \\
\text { Puanı }\end{array}$} & Sira & 10 & 11 & 10 & 11 & 12 & $\overline{10,8}$ \\
\hline & Puan & 4,6 & 5,1 & 10,2 & 6,7 & 6 & 32,6 \\
\hline
\end{tabular}

Kaynak: UEFA Club Coefficients (2010-2015)

Tablo 14'te yer alan 2010 Ağustos-2015 Mayıs arası UEFA Avrupa kupalarında takım siralamalar1 ve toplanan puanlar incelendiğinde, tüm sezonlarda sıralamaya giren takımlar içerisinde en yüksek sıra ortalaması 44 ile Galatasaray’’n olduğu görülmektedir. Takımların puanlarına bakıldığında 2010 Ağustos2015 Mayıs arasında 43,5 puan ile Galatasaray ülke puanına en çok katkı yapan kulüptür. Kulüplerin Avrupa kupalarında topladı̆̆1 puanlara göre belirlenen ülke sıralaması ve puanına göre Türkiye'nin 2010 Ağustos-2015 Mayıs arasında 54 ülke içerisinde ortalama sırasının 10,8 olduğu toplam puanının ise 32,6 olduğu görülmektedir.

Tablo 15. 2015 Ağustos-2020 Temmuz, Arası UEF A Takım Siralamalar ve Toplanan Puanlar

\begin{tabular}{|c|c|c|c|c|c|c|c|}
\hline \multicolumn{2}{|c|}{ Kulüp Adı } & \multirow{2}{*}{$\frac{2015-2016}{32}$} & \multirow{2}{*}{$\frac{2016-2017}{31}$} & \multirow{2}{*}{$\frac{2017-2018}{51}$} & \multirow{2}{*}{$\frac{2018-2019}{68}$} & \multirow{2}{*}{$\frac{2019-2020}{64}$} & \multirow{2}{*}{$\begin{array}{c}\begin{array}{c}2015-2020 \\
\text { Ortalama }\end{array} \\
49,2\end{array}$} \\
\hline Golatacarav & Sira & & & & & & \\
\hline Galatasaray & Puan & 9 & - & 1 & 8 & 6 & 24 \\
\hline \multirow{2}{*}{ Trabzonspor } & Sira & 59 & 80 & 76 & 142 & 170 & 105,4 \\
\hline & Puan & 1 & - & - & - & 3 & 4 \\
\hline \multirow{2}{*}{ Fenerbahçe } & Sira & 52 & 39 & 61 & 45 & 52 & 49,8 \\
\hline & Puan & 12 & 10 & 1,5 & 8 & - & 31,5 \\
\hline \multirow{2}{*}{ Beşiktaş } & Sira & 62 & 43 & 26 & 25 & 28 & 36,8 \\
\hline & Puan & 7 & 20 & 19 & 5 & 3 & 54 \\
\hline \multirow{2}{*}{$\begin{array}{l}\text { Medipol } \\
\text { Başakşehir }\end{array}$} & Sira & 194 & 158 & 140 & 118 & 71 & 136,2 \\
\hline & Puan & 1 & 1,5 & 6 & 2 & 11 & 21,5 \\
\hline \multirow{2}{*}{ Osmanlispor } & Sira & - & 122 & 149 & 141 & 142 & - \\
\hline & Puan & - & 8 & - & - & - & 8 \\
\hline \multirow{2}{*}{ Konyaspor } & Sira & - & 162 & 154 & 156 & 168 & - \\
\hline & Puan & - & 2 & 5 & - & - & 7 \\
\hline \multirow{2}{*}{ Akhisarspor } & Sira & - & - & - & 159 & 172 & - \\
\hline & Puan & - & - & - & 3 & - & 3 \\
\hline \multirow{2}{*}{$\begin{array}{l}\text { Yeni } \\
\text { Malatyaspor }\end{array}$} & Sira & - & - & - & - & 171 & - \\
\hline & Puan & - & - & - & - & 2 & 2 \\
\hline \multirow{2}{*}{$\begin{array}{l}\text { Türkiye Ülke } \\
\text { Puanı }\end{array}$} & Sira & 11 & 11 & 10 & 10 & 11 & 10,6 \\
\hline & Puan & 6,6 & 9,7 & 6,8 & 5,5 & 5 & 33.6 \\
\hline
\end{tabular}

Kaynak: UEFA Club Coefficients (2015-2020) 
2015 Ağustos-2020 Temmuz arası UEFA Avrupa kupalarında takım sıralamaları ve toplanan puanlar incelendiğinde, tüm sezonlarda sıralamaya giren takımlar içerisinde en yüksek sıra ortalamas1 36,8 ile Beşiktaş olduğu görülmektedir. Takımların puanlarına bakıldı̆̆ında 2015 Ağustos-2020 Temmuz arasında 54 puan ile Beşiktaş ülke puanına en çok katkı yapan kulüptür. Kulüplerin Avrupa kupalarındaki başarılarına göre belirlenen ülke sıralaması ve puanları incelendiğinde Türkiye 2015 Ağustos-2020 Temmuz arasında 55 ülke içerisinde 10,6 ortalama sırada yer alırken, bu sezonlarda toplam 33,6 puan elde etmiştir.

Tablo 16. 2010 Ağustos-2015 Mayıs Arası Türkiye'nin FIF A Siralamasındaki Yeri

\begin{tabular}{|c|c|c|c|c|c|}
\hline Ay & $\begin{array}{c}2010-2011 \\
\text { Siralama }\end{array}$ & $\begin{array}{c}\text { 2011-2012 } \\
\text { Siralama } \\
\end{array}$ & $\begin{array}{c}2012-2013 \\
\text { Siralama }\end{array}$ & $\begin{array}{c}\text { 2013-2014 } \\
\text { Siralama }\end{array}$ & $\begin{array}{c}2014-2015 \\
\text { Siralama }\end{array}$ \\
\hline Temmuz & 28 & 24 & 29 & 57 & 32 \\
\hline Ağustos & 28 & 24 & 30 & 58 & 32 \\
\hline Eylül & 21 & 27 & 35 & 49 & 38 \\
\hline Ekim & 29 & 26 & 36 & 40 & 46 \\
\hline Kasım & 29 & 28 & 38 & 43 & 48 \\
\hline Aralık & 31 & 28 & 40 & 43 & 49 \\
\hline Ocak & 31 & 29 & 40 & 45 & 48 \\
\hline Şubat & 31 & 25 & 41 & 42 & 52 \\
\hline Mart & 32 & 32 & 45 & 38 & 56 \\
\hline Nisan & 30 & 33 & 44 & 39 & 52 \\
\hline Mayıs & 30 & 33 & 44 & 39 & 52 \\
\hline Haziran & 23 & 33 & 54 & 35 & 57 \\
\hline Ortalama Sira & 28.58 & 28.5 & 39.66 & 44 & 46.83 \\
\hline \multicolumn{3}{|c|}{ 2010-2015 Ortalama Sira } & & 37.51 & \\
\hline
\end{tabular}

Kaynak: FIFA Men's Ranking, (2010).

Tablo 16'da FIFA tarafindan aylık olarak açıklanan A milli takım düzeyinde ülke puanlarına, UEFA puanları ile paralellik olması açısından, 2010-Temmuz ve 2015-Haziran arasını kapsayacak şekilde yer verilmiştir. Bu verilere göre FIFA sıralamasında Türkiye'nin ortalama sıralamasının 2010-2011 sezonunda 28,58 olduğu, 2011-2012 sezonunda 28,5 olduğu, 2012-2013 sezonunda 39,66 olduğu, 2013-2014 sezonunda 44 olduğu ve 2014-2015 sezonunda 46,83 olduğu görülmektedir. 2010 Ağustos - 2015 May1s arasında genel ortalama siranın ise 37,51 olduğu görülmektedir.

Tablo 17. 2015 Ağustos-2020 Temmuz, Arası Türkiye'nin FIFA Siralamasindaki Yeri

\begin{tabular}{|c|c|c|c|c|c|}
\hline$A y$ & $\begin{array}{c}2015-2016 \\
\text { Siralama }\end{array}$ & $\begin{array}{c}\text { 2016-2017 } \\
\text { Siralama }\end{array}$ & $\begin{array}{c}2017-2018 \\
\text { Siralama }\end{array}$ & $\begin{array}{c}2018-2019 \\
\text { Siralama }\end{array}$ & $\begin{array}{c}2019-2020 \\
\text { Siralama }\end{array}$ \\
\hline Temmuz & 48 & 19 & 33 & 35 & 37 \\
\hline Ağustos & 45 & 19 & 33 & 38 & - \\
\hline Eylül & 46 & 21 & 27 & 38 & 36 \\
\hline Ekim & 37 & 25 & 33 & 38 & 32 \\
\hline Kasım & 18 & 24 & 42 & 39 & 29 \\
\hline Aralık & 21 & 24 & 42 & 39 & 29 \\
\hline Ocak & 21 & 24 & 41 & - & - \\
\hline Şubat & 20 & 24 & 38 & 41 & 29 \\
\hline Mart & 20 & 26 & 38 & - & - \\
\hline Nisan & 13 & 22 & 37 & 39 & 29 \\
\hline Mayıs & 13 & 22 & 37 & - & - \\
\hline Haziran & 18 & 25 & 38 & 37 & 29 \\
\hline Ortalama Sira & 26,66 & 22,91 & 36,58 & 38,22 & 31,25 \\
\hline \multicolumn{3}{|c|}{ 2015-2020 Ortalama Sıra } & & 31,124 & \\
\hline
\end{tabular}

Kaynak: FIFA Men's Ranking, (2015). 
Tablo 17'de FIFA tarafından aylık olarak açıklanan A milli takım düzeyinde ülke puanlarına, UEFA puanları ile paralellik olması açısından, 2015-Temmuz ve 2020-Haziran arasını kapsayacak şekilde yer verilmiştir. Bu verilere göre FIFA sıralamasında Türkiye'nin ortalama sıralamasının 2015-2016 sezonunda 26,66 olduğu, 2016-2017 sezonunda 22,91 olduğu, 2017-2018 sezonunda 36,58 olduğu, 2018-2019 sezonunda 38,22 olduğu ve 2019-2020 sezonunda 31,25 olduğu görülmektedir. 2015 Ağustos - 2020 Temmuz arasında genel ortalama sıranın ise 31,124 olduğu görülmektedir.

Tablo 18. 2010-2020 Türkiye A Milli Futbol Takımı Kadrosunda Yer Alan Yurtdısındaki Futbolcular

\begin{tabular}{cccc}
\hline Yll & $\begin{array}{c}\text { Yurtdisindaki Futbolcu } \\
\text { Sayıs1 }\end{array}$ & Toplam Futbolcu & $\begin{array}{c}\text { Yurtdisindaki Futbolcu } \\
\text { Yüzdesi (\%) }\end{array}$ \\
\hline 2010 & 13 & 54 & $\% 24,07$ \\
2011 & 11 & 48 & $\% 22,91$ \\
2012 & 15 & 48 & $\% 31,25$ \\
2013 & 8 & 51 & $\% 15,68$ \\
2014 & 7 & 54 & $\% 12,96$ \\
2015 & 7 & 40 & $\% 17,5$ \\
\hline & 2010-2015 Ortalama Futbolcu Yüzdesi (\%) & $\% \mathbf{2 0 , 6 7}$ \\
2016 & 14 & 52 & $\% 26,92$ \\
2017 & 11 & 41 & $\% 26,82$ \\
2019 & 15 & 52 & $\% 39,84$ \\
2020 & 13 & 33 & $\% 53,57$ \\
\hline
\end{tabular}

Kaynak: Türkiye A Milli Takım Kadrosu, (2010-2020).

Tablo 18'e bakıldığında Türkiye A Milli Futbol Takımı kadrosuna seçilmiş ve yabancı kulüplerde yer alan futbolcular görülmektedir. Türkiye Süper Liginde 2015-2016 sezonundan itibaren uygulamaya konulan yabancı futbolcu düzenlemesinin Türkiye Milli Futbol Takımına etkileri 2016 yllndan itibaren görülmektedir. 2016 yılından itibaren Milli Takımda yer alan ve yurtdışındaki kulüplerde yer alan futbolcuların oranı artmaya başlamıştır. 2010-2015 yılları arasında yurtdışındaki kulüplerde yer alan A Milli futbolcuların oranı \%20,67 iken 2016-2020 yilları arasında bu oran \%33'e çıkmıstır.

\section{Tartışma ve Sonuç}

Çalışma bulguları incelendiğinde 2010-2015 sezonları arasında toplam futbolcuların \%67,08’i Türk Vatandaşı futbolcuyken, \%32,91’i yabancı futbolcu olmuştur. 2015-2020 sezonları ise toplam futbolcuların \%56,53'ü Türk Vatandaş1 futbolcuyken, \%43,46's1 yabanc1 futbolcu olmuştur. Bu verilere göre, değişken yabanc1 sinırı uygulamasinın yapıldığ1 2010-2015 sezonları arasında yabanc1 futbolcu sayısının toplam futbolcu sayısina oranı \%32,91 iken, 2015-2020 sezonları arasinda bu oran \%43,46 olarak, \%10,55 oranında bir artış olduğu görülmektedir. Bu verilere karşılık 2010-2015 sezonları arası müsabakalarda görev alan yabanc1 futbolcuların ortalama oranı 35,99 iken bu oran 2015-2020 sezonları arasında 52,64 olmuş ve $\%$ 16,65 oranında artış gerçekleşmiştir. Ayrıca 2010-2015 sezonları arası yabanc1 futbolcuların müsabakalardaki ortalama görev süresi oranı \%42,58 iken bu oran 2015-2020 sezonları arasında \%60,41 olmuş ve $\% 17,83$ oranında bir artış gerçekleşmiştir.

Diğer etkenlerden bağımsız olarak yabanc1 futbolcu düzenlemesinin etkilerinin tespit edilmesi amacıyla kulüplerin UEFA organizasyonlarına katılım durumu ve Türkiye'nin ülke puanı incelendiğinde 2010-2015 sezonları arasında 54 ülke içerisinde ortalama sıranın 10,8 olduğu toplam puanının ise 32,6 olduğu tespit edilmiştir. Türkiye 2015-2020 sezonları arasında ise 55 ülke içerisinde 10,6 ortalama sırada yer alırken, bu sezonlarda toplam 33,6 puan elde etmiştir. Bu verilere göre Türk kulüplerinin UEFA başarısına göre belirlenen sıralamada 1 puanlık bir artış olduğu tespit edilmiştir.

Türkiye'nin FIFA sıralamasına bakıldığında ise 2010-2015 sezonları arasında genel ortalama sıra 37,51 iken, 2015-2020 sezonları arasında genel ortalama sıranın 31,124 olduğu tespit edilmiştir. İlgili sezonlarda Türkiye FIFA sıralaması ortalamasında yaklaşık 6 sıra daha üstte yer almıştır.

Türkiye Futbol Federasyonu tarafindan 2015-2016 sezonundan itibaren uygulamaya konulan yabanc1 futbolcu düzenlemesinin kulüplerin UEFA organizasyonları başarısına göre sınırlı bir artış olduğu görülse 
de Türkiye Milli Takımının FIFA sıralamasında artısıın daha belirgin olduğu söylenebilir. Buradan hareketle yabancı futbolcu sayısının artırılmasının milli takım düzeyinde olumsuz bir etkisinin olmadığı söylenebilir. Bunun yanında Türkiye A Milli Futbol Takımı kadrosuna seçilmiş ve yabancı kulüplerde yer alan futbolcuların oranının da belirgin bir şekilde arttı̆̆ görülmektedir. A milli takımda 2010-2015 yılları arasında yer alan yurtdış kulüplerde yer alan futbolcuların oranı \%20,67 iken 2016-2020 yılları arasında bu oran \%33'e çıkmıştır. Son yıllarda Avrupa'nın büyük kulüplerinde forma şansı bulan Türk Milli Takımı futbolcularındaki artıs göz önünde bulundurulduğunda günümüzde uygulanan yabanc1 futbolcu düzenlemesinin A Milli Futbol Takımını olumsuz etkileyeceği görüşünün tam olarak doğru olmadığı söylenebilir.

Gündüz, Shamatava ve Sayan (2019, s.66), çalışmalarında yabanc1 futbolcu düzenlemesinin, başarı noktasında Türk futboluna ya da Milli takıma herhangi bir olumlu katkısı olmadığını belirterek, Milli takımın ve Türk futbol kulüplerinin, uluslararası müsabakalarda ya da turnuvalarda ciddi başarı elde edemediğini belirterek ülkenin genel spor politikası, kulüplerin transfer politikaları ve mali yapılarının yeniden düzenlenerek, futbolculara sağlanan psikolojik desteklerin (özellikle altyapıda) artırılması gerektiğini belirtmiştir. Arslan'da (2020, s. 58) saha içinde 11 yabanc1 futbolcunun yer alabildiği düzenlemenin Türk futboluna uluslararası başarı açısından herhangi bir etkisinin olmadığını belirterek sayısal sınırlamalar yerine niteliksel sinırlamalara dayalı bir transfer politikası uygulanması gerektiğini belirtmiştir.

Yüce, Katırcı ve Kuzu (2017) çalışmalarında yabancı futbolcu düzenlemesinin Türk futbolunda kaliteyi artıracağı beklentilerinin aksine bir sonuç olduğunu, müsabakalardaki ortalama seyirci sayısının düştüğünü ve Türk futbolunda istenilen hedefleri gerçekleştiremediğinden düzenlemenin tekrar ele alınarak Türk futboluna katkı sağlayacak biçimde yeniden düzenlenmesi gerektiğini belirtmiştir.

Çalışmalarda yabancı futbolcu düzenlemesinin herhangi bir etkisi olmadığı belirtilse de maç günü gelirleri, ticari gelirleri ve naklen yayın gelirleri toplamı 2015-2016 sezonunda 2 milyar TL, 2016-2017 sezonunda 2,3 milyar TL, 2017-2018 sezonunda 3,2 milyar TL olan kulüplerin, toplam gelirleri 2018-2019 sezon sonu itibarıly 4,2 milyar TL'ye ulaşmıştır (Ekolig, 2019, s. 100). Müsabakalara 11 yabanc1 futbolcunun çıkabildiği bu süreçte Süper Lig kulüplerinin gelirleri sürekli artış göstermiştir.

Yabancı futbolcu düzenlemesinin etkilerinin elbette ki kısa vadede ortaya çıması mümkün değildir ve etkisi gelecekte belirgin olacaktır. Dolaysıyla yapılan değişikliklerin etkileri tam olarak tespit edilmeden yeni bir düzenlemenin yapılması yarardan çok zarar verecektir. Bununla birlikte değişiklik kararları paydaşların görüşleri alınarak uygulanmalıdır (Charyev, 2014, p. 12). Bunun için yabancı futbolcu sinırlamasının nasıl olması gerektiği ile ilgili futbol federasyonu, kulüpler ve ilgili paydaşlardan görüş isteyip, diğer ülkelerdeki yabancı futbolcu uygulamaları da dikkate alınarak en uygun düzenlemenin tespit edilmesi mümkün olabilecektir.

Konu ile ilgili bir başka eleştiri olan taraftar sayısındaki düşüşün ise 2014 yllı nisan ayında uygulamaya konulan Passolig düzenlemesi nedeniyle olduğu söylenebilir. Passolig uygulamasının çıktı̆̆ı ilk yıl seyirci ortalamasında önemli oranda düşüş yaşanmış olmasına rağmen, sonraki sezonlarda ortalama seyirci sayısında devamlı bir artış olmuştur (Mumcu ve Karakullukçu, 2019, s. 52). Ancak 2019-2020 sezonu 26. Haftadan itibaren Covid-19 Pandemisi nedeniyle seyirci yasağı uygulanmışıtır (TFF, 2020).

Fişne ve Bardakçı (2019, s. 572) konuyla ilgili taraftar görüşlerini incelemek için gerçekleştirdikleri çalışmada, katılımcıların en az yarısının yabancı futbolcu sayısının sınırlandırılmasına karşı olduğunu ve sınırlandırmanın ligin kalitesini düşüreceği, Türk Vatandaşı futbolcuların bonservislerinde gereksiz yükselme olacağı, Türk takımlarının Avrupa kupalarındaki başarısını ve dolayısıyla elde edeceği gelirleri azaltacağını, Türk Vatandaşı futbolcuların gelişiminde yabancı futbolcuların oynadıklanı önemli rolü kaybedecekleri ve Türk futbolunun tanınırlığına ve bilinirliğine olumsuz etkileri olacağı vb. endişeleri olduğunu belirtmişlerdir. Yabanc1 sınırı olması gerektiğini savunan taraftarlar ise, fazla sayıda yabanc1 olmasının Türk futbolcuların oynama şansını azaltmasının milli takıma olumsuz yansıyacağı ve kulüplerin transferde savurganca davranması nedeniyle ekonomik sorunlar yaşayacakları vb. nedenler öne sürmüşlerdir.

Demir'e (2020, s. 373) göre, endüstriyelleşme ile birlikte bir yatırım aracına dönüşen futbol artık mutlak sonuç ve sonuç üzerinden elde edilen rant için oynanmaktadır. Akşar (2013) ise, Türk futbolunda esas sorunun, futbol örgütlenme yapisının ve sistemin doğru oluşturulamamış olmasından, dengesiz ve haksız rekabetten, yetersiz kurumsallıktan, yetersiz denetimden ve kaynakların etkili ve verimli 
kullanılmamasından kaynaklandığını belirtmiştir. Tüm bu sıralananların yanında kulüplerde altyap1 yetersizlikleri de önemli bir sorun olarak görülmektedir. Çevik ve Onağ (2019, s. 342) çalışmalarında, altyapılarda organizasyonel ve sistemsel düzensizliklerin olduğunu, tesislerde, eğitim plan ve programlarında, altyapıdan sorumlu personelde, denetim mekanizmalarında ve maddi imkânlarda yetersizlikler olduğu sonucuna ulaşmışlardır. Çetinkaya ve Yıldırım (2021, s. 184) ülkemizde, uzun vadede katma değer sağlayacak genç futbolculara yönelimin az olmasının en önemli sebebinin, kulüpler ve teknik adamlar üzerinde oluşturulan kısa sürede başarı elde etme baskısı olduğunu ifade etmiştir.

Bugün birçok kulübün elde etmiş olduğu gelirler, borçlarını kapatmaya yetmemekte ve dahası, faiz giderlerini bile karşılamaya imkân tanımamaktadır. Bu durum ise, kulüplerin sürekliliklerini tehlikeye sokarak, onlar için özellikle finansal anlamda ciddi sorunlar teşkil etmektedir (Yilmaz, 2020, s. 517). Günümüz futbolunda sürdürülebilir başarı, sağlıklı ve sürdürülebilir bir mali yapı kurulmasına, finansal enstrümanların iyi kullanılmasına, takım değerlerinin, marka değerlerinin ve piyasa değerlerinin maksimize edilmesine bağlıdır (Akşar, 2020, s.3). Kulüplerin, futbolun finansmanında disiplini ve rasyonelliği getirecek stratejik eylem planları geliştirmeleri ve etkin maliyet yönetimini sağlamaları gerekmektedir. Denk bütçe uygulaması ile gelir ve gider dengesini sağlayabilen kulüplerde finansal istikrarın temin edilmesine olan gereksinim ön plana çıkmaktadır (Güngör, 2014b, s. 156). Dolayısıyla kulüplerin, gelir-gider yapılarını çok iyi bir şekilde kontrol etmeleri, maç günü gelirleri, ticari gelirler ve yayın gelirlerinden oluşan birincil gelir kaynaklarını dikkatli bir şekilde yönetmeleri ve dengelemeleri gerekmektedir. Futbolcu transferi ve yeni girişimci faaliyetler için daha sistematik bir yaklaşım benimsenerek ikincil gelir kaynaklarının artırılması, sportif başarıyı engellemeden sabit ve değişken giderlerin mümkün olduğu kadar azaltılması ve kulüplerin ticari ve futbol bölümlerinde yetenekli ve profesyonel personel istihdam edilerek güçlü bir kurumsal yapı oluşturmaları gerekmektedir (Uluyol, 2014, s. 5729). Bu kapsamda kulüplerin daha disiplinli ve mantıklı bir şekilde yönetilmesini sağlamak amacıyla UEFA tarafindan Finansal Fair-Play düzenlemesi uygulamaya konmuştur. Finansal Fair-Play kriterlerine uyum sağlayan kulüpler, süreklilikleri açısından herhangi bir tehdit unsuru oluşturmayan daha sağlıklı bir finansal yapıya sahip olurken, söz konusu kriterlere uymayan kulüpler iflas riski ile karşı karşıya kalmaktadır. Bu riskin ortaya çıłmasında ise kulüplerin endüstriyel futbolun gerekliliklerine tam anlamıyla uyum sağlayamamasının yattığı görülmektedir (Yilmaz, 2020, s. 518).

Ersoy, Çıtak ve Gülal (2016, s. 147) çalışmalarında transfer harcamalarının artırılması ve takımların futbolcularının toplam piyasa değerinin yükselmesi durumunda, futbol kulüplerinden beklenen sportif başarı düzeyinin yükseleceğini ve ayrıca transfer harcamalarındaki artışla birlikte, seyirci sayısı, bilet satış gelirleri ve diğer gelirlerin de artmasının bekleneceğini belirtmiştir. Ancak bu beklentilerin her zaman istenen düzeyde gerçekleşmediği görülmektedir. Günümüzde futbolcu transfer etmek futbolcuyu göndermekten daha kolaydır. Transfer yöntemi ve süreçleri her ne kadar futbolcu alımı üzerinden değerlendirilse de, futbolcu satışı da yöntem ve süreçler içermektedir (Peçenek, 2020, s. 37). Alınan futbolcuları göndermek için kulüpler çoğu kez maddi zarara uğramaktadır. Bu nedenle mümkün olan ölçüde az sayıda transfer yapılması hedeflenmelidir. Transfer edilen futbolcuların, gönderilmek istendiğinde çabuk transfer edilebilecek futbolcular olmasına azami ölçüde dikkat edilmesi bir gereklilik olarak karşımıza çıkmaktadır (Çetinkaya ve Yıldırım, 2021). Yıldırım (2008, s. 90), yabancıların Türkiye'de futbol oynamayı isteme nedenlerinin tamamen ekonomik olduğunu ve özel isteklerinin (ev, araba vb.) kulüp tarafından sorunsuz bir şekilde karşılandığı tespit edilmiştir. Ayrıca ekonomik problemleri kulübü tarafından genellikle sorunsuz bir şekilde ve öncelikli olarak halledilmesine rağmen, ödemelerde gecikmeler yaşanması durumunda, yabancı futbolcuların kulübünden ayrılmak istediği belirtilmiştir. Dolayısıyla bu tür durumlarla karşılaşmamak için futbolcularla imzalanan sözleşme şartlarına dikkat etmek gerekmektedir.

Çalışma sonucunda bir değerlendirme yapılacak olursa, ülkemizde tek profesyonel spor dalı olarak kabul edilen futbolda, federasyondan kulüplere tüm kurumların profesyonelce yönetilmediği, sistemsel ve yapısal problemlerin göz ardı edildiği, kısa vadeli başarıya odaklanılarak yanlış kararlar alındığı, finansal kaynakların rasyonel değerlendirilmediği, gelir-gider dengesinin sağlanamadı̆̆ı, altyapıya ve genç futbolculara gereken değerin verilmediği vb. birçok sorun sıralanabilir. Türk futbolunda asıl odaklanılması gereken konu yabancı futbolcuların statüsü değildir. Tüm kurumsal yapıdaki sorunların çözümüne yönelik ayrıntılı analizler yapılarak stratejik planlar oluşturulması ve bu planların profesyoneller tarafindan uygulanmasi gerekmektedir. 


\section{Etik Beyan}

"Türkiye Futbol Süper Liginde Yabancı Futbolcu Düzenlemesinin Değerlendirilmesi”" başlıklı çalısmanın yazım sürecinde bilimsel kurallara, etik ve alıntı kurallarına uyulmuş; toplanan veriler üzerinde herhangi bir tahrifat yapılmamış ve bu çalışma herhangi başka bir akademik yayın ortamına değerlendirme için gönderilmemiştir. $\mathrm{Bu}$ araştırma doküman incelemesine dayalı olarak yapıldığından etik kurul kararı zorunluluğu bulunmamaktadır.

\section{Kaynakça}

Akşar, T. (2013). 6+0+4 ÜZৃerine Farkl Bir Bakııs. Erişim adresi: https://www.dunya.com/kose-yazisi/604-uzerinefarkli-bir-bakis/17052 (19.03.2021).

Akşar, T. (2020). Finansal futbol. İstanbul: Literatür Yayıncilı.

Akşar, T. ve Merih, K. (2008). Futbol yönetimi. İstanbul: Literatür Yayıncillk.

Arslan, K. (2020). Yabancı futbolcu statüsü ve bassar iliskisi: Türkiye ve 'bess büyük' Avrupa futbol ligi üzerine bir arastrma (Yüksek Lisans Tezi). Ege Üniversitesi, Sağlık Bilimleri Enstitüsü, İzmir.

Bıçakçı, L. (2015-Nisan). Futbol ekonomisi nereye gidiyor? Capital Genis Aç, 4-29.

Charyev, G. (2014). Consequences of the limit on foreign players in russian football. Soccer \& Society, 17(4): 571-587. https://doi.org/10.1080/14660970.2014.980727

Çetinkaya, G. ve Yıldırım, Ü. (2021). Türk futbolundaki yabancı futbolcu transferlerinin kâr-zarar analizi. The Journal of Social Science, 5(9), 176-188. https://doi.org/10.30520/tjsosci.846934

Çevik, S. ve Onağ, Z. (2019). Türkiye'de altyapıdan futbolcu yetişememesinin nedenleri ve çözüm önerileri üzerine nitel bir araştırma. CBÜ Beden Eğitimi ve Spor Bilimleri Dergisi, 14(2), 326-343. https://doi.org/10.33459/cbubesbd.637214

Demir, M. (2020). Endüstriyel futbol ve futbolda teknoloji kullanımı. TRT Akademi, 5(9), 356-375. Erişim adresi: https://dergipark.org.tr/tr/pub/trta/issue/52035/678195

Ekolig (2019). 2017-2018/2018-2019 Sežnu raporu. Erişim adresi: https://www.aktifbank.com.tr/Documents/EkoligFinal-11112019.pdf (20.03.2021).

Ersoy, E., Çıtak, L. ve Gülal, Ö. (2016). Yerli ve yabancı futbol kulüplerinin transfer harcamaları bağlamında etkinliklerinin karşılaştırllması. Maliye ve Finans Yą̧ılar, O(105), 133-152. https://doi.org/10.33203/mfy.312139

FIFA (2010 February 3). Men's Ranking. Retrieved from https://www.fifa.com/fifa-world-ranking/rankingtable/men/rank/id9164/ (18.02.2021).

FIFA (2015 February 12). Men's Ranking. Retrieved from https://www.fifa.com/fifa-world-ranking/rankingtable/men/rank/id10999/ (18.02.2021).

Fişne, M. ve Bardakçı, S. (2019). Taraftarların bakış açısıyla türk futbolunda yabancı oyuncu sınırlamasına yönelik bir araştırma. MANAS Sosyal Araşttrmalar Dergisi, 8(1/1), 551-575. https://doi.org/10.33206/mjss.481502

Gündüz, B., Shamatava, K. ve Sayan, İ. (2019). Yabancı futbolcu sınırlamasının takımların ekonomilerine etkisi. International Sport Science Student Studies, 1(1), 58-68. Erişim adresi: https://dergipark.org.ttr/tr/pub/i4s/issue/50475/665377

Güngör, A. (2014a). Futbol endüstrisinde sportif başarı ile finansal performans arasındaki ilişkinin analizi ve türkiye uygulaması. İstanbul Üniversitesi Sosyal Bilimer Dengisis, 1, 16-36. Erişim adresi: https://dergipark.org.tr/tr/pub/iusosbil/issue/9504/118796

Güngör, A. (2014b): Avrupa futbol pazarının ekonomik boyutu ve Avrupa futbol kulüplerinde finansal performans analizi. İstanbul Gelişim Üniversitesi Sosyal Bilimler Dergisi, 1(2), 133-160. https://doi.org/10.17336/igusbd.29543

Karaman, S. (2019). Nitel araştırma süreci. İçinde S. Karaman (Edt.), Araştrma Yöntem ve Teknikleri II (ss. 22-47). Erzurum: Atatürk Üniversitesi Açıköğretim Fakültesi Yayını.

Mumcu, H.E. ve Karakullukçu, Ö.F. (2019). Passolig uygulamasının futbol izleyicisi üzerine etkileri. Çanakkale Onsekiz Mart Üniversitesi Spor Bilimleri Dernisi, 2(2), 46-57. Erişim adresi: https://dergipark.org.tr/tr/pub/comusbd/issue/51651/669070

Ntv Spor (2012, 30 Mayis). UEFA depremi! Erişim adresi: https://www.ntvspor.net/futbol/uefa-depremi579e4e63c873cc20ac3c8915 (03.03.2021).

Ntv Spor (2014, 07 Temmuz). CAS'tan kötü baber! Erişim adresi: https://www.ntvspor.net/futbol/castan-kotu-haber579e230fc873cc3eb4251a03 (03.03.2021).

Ntv Spor (2020, 03 Haziran). UEFA'dan Trabzonspor'a 1 yal men cezasl Erişim adresi: https://www.ntvspor.net/futbol/trabzonspor-a-avrupa-dan-men-cezasi-5ed7c43f2555981db01 fafe3 (03.03.2021).

Peçenek, A. (2020). Avrupa-Türkiye futbol piyasaları ve transfer yöntem ve süreçleri kiyaslaması. Spormetre Beden Eğitimi ve Spor Bilimleri Dergisi, 18(3), 31-41. https://doi.org/10.33689/spormetre.562104

Sönmez, V. ve Alacapınar, F.G. (2019). Örneklendirilmis bilimsel arasstrma yöntemleri (7. Baskı). Ankara: Anı Yayıncılık.

Süper Lig istatistikleri (2010-2011). Erişim adresi: https://www.tff.org/Resources/TFF/Documents/002011/istatistik/SLFutbolcularin-Oynadigi-dakika-KartGol-Sayilari-2.xls (23.02.2020). 
Süper Lig istatistikleri (2011-2012). Erişim adresi:

https://www.tff.org/Resources/TFF/Documents/0002012/Ligler/SuperLig/SezonSonuIstatistik/001-

Kulube-Gore-Futbolcularin-Ma\%C3\%A7-Sayisi-Oynama-Suresi-Sari-Kirmizi-Kart-Gol-Sayilari (23.02.2020).

Süper Lig istatistikleri (2012-2013). Erişim adresi:

https://www.tff.org/Resources/TFF/Documents/000013/LIGLER/SUPER-LIG/34-Hafta-

Istatistikleri/Fut-Oyn-Dakika-Kart-Gol\%20Sayilari.xls (23.02.2020).

Süper Lig istatistikleri (2013-2014). Erişim adresi:

https://www.tff.org/Resources/TFF/Auto/4800cf3f14934db18f7379e646c63608.xls (23.02.2020).

Süper Lig istatistikleri (2014-2015). Erişim adresi:

https://www.tff.org/Resources/TFF/Auto/e001ae9db8504fd5a35588e6d2cc8a19.xls (25.02.2020).

Süper Lig istatistikleri (2015-2016). Erişim adresi:

https://www.tff.org/Resources/TFF/Documents/00000016/Ligler/STSL/SezonSonuIstatistik/01-Kulube-

Gore-Futbolcularin-Mac-Sayisi-Oynama-Suresi-Sari-Kirmizi-Kart-Gol-Sayilari.xls (25.02.2020).

Süper Lig istatistikleri (2016-2017). Erişim adresi:

https://www.tff.org/Resources/TFF/Documents/LIGLER/Super-Lig/Istatistik/01-Kulube-Gore-

Futbolcularin-Mac-Sayisi-Oynama-Suresi-Sari-Kirmizi-Kart-Gol-Sayilari.xls (25.02.2020).

Süper Lig istatistikleri (2017-2018). Erişim adresi:

https://www.tff.org/Resources/TFF/Auto/b51aa591075b43adbb25f5dc0b42f9d4.xls (25.02.2020).

Süper Lig istatistikleri (2018-2019). Erişim adresi:

https://www.tff.org/Resources/TFF/Auto/a31d89946ed045e29997f75b631d615e.xls (25.02.2020).

Süper Lig istatistikleri $\quad$ (2019-2020). https:/ /www.tff.org/Resources/TFF/Documents/LIGLER/2019-2020/Istatistikler/Super-Lig-Sezon-SonuIstatistikleri.xls (25.02.2020).

Süper Lig kadro bilgileri (2010-2015). Erişim adresi: https://www.transfermarkt.com/superlig/startseite/wettbewerb/TR1/plus/?saison_id=2010 (01.10.2020).

Süper Lig kadro bilgileri (2015-2020). Erişim adresi: https://www.transfermarkt.com/superlig/startseite/wettbewerb/TR1/plus/?saison_id=2015 (01.10.2020).

Şar, F. (2007). Yabancı oyuncu sınırlaması Türk ve Avrupa Birliği hukuku açısından incelenmesi. İçinde K. Erkiner (Edt.), Spor Hukuku Tezleri (ss. 529-573). İstanbul: Kadir Has Üniversitesi Yayınları.

TFF (2011a, 24 Ağustos). Fenerbahçe, Şampiyonlar Ligi'ne katılamayacak. Erişim adresi: https://www.tff.org/default.aspx?pageID=285\&ftxtID=13257 (03.03.2021).

TFF (2011b, 24 Ağustos). Şampiyonlar Ligi'ne Trabronspor katılacak. Erişim adresi: https:/ /www.tff.org/default.aspx?pageID=285\&ftxtID=13261 (03.03.2021).

TFF (2020, 12 Mart). Koronavirüs (Kovid-19) tedbirleri ve seyircisiz oynanacak maçlar hake.knda. Erişim adresi: https: / /www.tff.org/default.aspx?pageID=687\&ftxtID=33152 (23.03.2021).

TFF Müsabaka Statüleri, (2019-2020). Süper Lig Cemil Usta Sezonu Müsabakalar Statüsü. Erişim adresi: https://www.tff.org/Resources/TFF/Documents/STATULER/2019-2020/2019-2020-SL-STATU.pdf (18.02.2021).

TFF Statüsü (2019). Erişim adresi: https://www.tff.org/Resources/TFF/Documents/TFF-KANUN-STATU/TFFStatusu.pdf (18.02.2021).

Türkiye A Milli Takım Kadrosu, (2010-2020). Erişim adresi: https://www.transfermarkt.com.tr/turkiye/kader/verein/3381/plus/0/galerie/0?saison_id=2010 (18.02.2021).

Türkiye Futbol Federasyonu Müsabaka Statüleri (2010-2020). Süper Lig müsabaka statüleri. Erişim adresi: https://www.tff.org/default.aspx?pageID=133 (18.02.2021).

UEFA (2016, March 2). CFCB Adjudicatory Chamber renders Galatasaray decision. Retrieved from https://www.uefa.com/insideuefa/protecting-the-game/news/022b-0e9386115232-60972a488826-1000--cfcbadjudicatory-chamber-renders-galatasaray-decision/ (03.03.2021).

UEFA Club Coefficients, (2010-2015). Retrieved from https://www.uefa.com/memberassociations/uefarankings/club/\#/yr/2011 (18.02.2021).

UEFA Club Coefficients, (2015-2020). Retrieved from https://www.uefa.com/memberassociations/uefarankings/club/\#/yr/2016 (18.02.2021).

Uluyol, O. (2014). Süper Lig futbol kulüplerinin finansal performans analizi. Journal of Yaşar University, 9(34), 57165731. https://doi.org/10.19168/jyu.78102

Yıldırım, E. (2008). Profesyonel ligdeki yabancı futbolcularn, türkiye'de futbol oynamalarna iliskin, ekonomik, sosyal ve kültürel açıdan görüsleri ve yerli futbolcularn yabancı futbolculara bakıss açılar (Doktora tezi). Gazi Üniversitesi, Sağlık Bilimleri Enstitüsü, Ankara.

Yıldırım, G. (2019). Araştırma yöntemleri. İçinde S. Karaman (Edt.), Araştırma Yöntem ve Teknikleri I (ss. 84-109). Erzurum: Atatürk Üniversitesi Açıköğretim Fakültesi Yayını.

Yılmaz, A.H. (2020). Endüstriyel futbolda finansal istikrarın önemi. Fiscaoeconomia, 4(2), 498-523. https://doi.org/10.25295/ fsecon.2020.02.012

Yüce, A, Katırc1, H. ve Kuzu, C. (2017). Türk futbolunda yabanc1 futbolcu sinırlaması ve Türk futbolcuların görüşleri. CBÜ Beden Eğitimi ve Spor Bilimleri Dergisi, 12(2), 24-39. 
https://dergipark.org.tr/tr/pub/cbubesbd/issue/33059/318544

\section{EXTENDED ABSTRACT}

The aim of this research is to evaluate the regulations regarding the restriction of foreign players applied in Turkish football in the last ten seasons. The research is considered to be important in terms of providing insight into possible future arrangements.

Descriptive research model used in the study and data required by the end of each season Turkey Football Federation has created the underlying data source documents containing statistical study of shared club. In addition, statistical databases related to the subject of the study were also used.

Within the scope of the study, between the 2010-2011 season and the 2019-2020 seasons, the number of Turkish citizens and foreign football players in the super league football clubs and the total time served in the competitions were analyzed and the frequency and percentage values were obtained. In addition, the country score obtained as a result of the European cup successes of Turkish football clubs between the 2015-2020 seasons was compared with the country score between the 2010-2011 season in which the foreign player restriction was applied and the 2014-2015 seasons. Moreover FIFA rankings success between the years 2010-2020 were analyzed to Turkey's national football team as a relational arrangements with foreign players. Country scores announced by FIFA were not included in the study due to the use of different scoring systems between 2006-2018 and after 2018. In order to determine the effects of foreign football player restrictions on the national team cadres, staff analysis between the years 2010-2020 was conducted. Players are encoded in the study refers to as Turkish citizens have the quality players to take part in the national football team to Turkey. Footballers who are Turkish citizens and are in the national team of another country have been evaluated as foreigners. Microsoft Excel program was used for statistical analysis. Turkey Football Super League analyzed in the study was made considering restrictions on foreign players. Football rules and restrictions, which are not related to foreign football player regulations, have not been taken into account in the analysis.

According to the findings of the study, $67.08 \%$ of the total football players were Turkish citizens, while $32.91 \%$ were foreign players between the $2010-2015$ seasons. In the $2015-2020$ seasons, $56.53 \%$ of the total footballers were Turkish citizens, while $43.46 \%$ were foreign players. According to these data, the ratio of the number of foreign football players to the total number of players was $32.91 \%$ between the 2010-2015 seasons when the variable foreign limit application was implemented, while this rate was $43.46 \%$, an increase of $10.55 \%$ between the $2015-2020$ seasons. In contrast to these data, the average rate of foreign football players taking part in the competitions between the 2010-2015 seasons was 35.99, while this ratio was 52.64 between the $2015-2020$ seasons and an increase of $16.65 \%$ was realized. In addition, the average tenure rate of foreign football players in the competitions between the 2010-2015 seasons was $42.58 \%$, while this rate was $60.41 \%$ between the $2015-2020$ seasons and an increase of $17.83 \%$ was realized.

When the other to determine the effects of foreign players regulation factors independently from the purpose of participation in clubs and UEFA organizational status and Turkey's sovereign rating is examined and the average order within 54 countries between 2010-2015 season 10,8 where total score is observed that 32.6. Turkey 2015-2020 season that ranks among the 10.6 average in 55 countries, has acquired a total of 33.6 points this season. According to these data, it is seen that there is a 1 point increase in the ranking determined according to the UEFA success of Turkish clubs.

When Turkey's views on the FIFA rankings, while the overall average 2010-2015 season between rows $37.51,31.124$ is seen that as the overall average between 2015-2020 season. Turkey in the FIFA rankings in relevant season average was approximately 6 rows above them.

Turkey Football Federation by the 2015-2016 UEFA organization of the club foreign players arrangements put into practice since the season there was a limited increase compared to the success of the rise in Turkey National Team of the FIFA rankings, there is more pronounced. Based on this, it can be said that increasing the number of foreign football players does not have a negative effect on the national team level. Besides, the Turkey national football team squad selected and located in the proportion of foreign players in club also has increased markedly. While the ratio of foreign football players who took part in the national team between 2010-2015 was $20.67 \%$, this rate increased to $33 \%$ between 2016-2020. Considering the increase in the Turkish National Team players who have had the chance to form in the big clubs of Europe in recent years, it can be said that the opinion that the foreign 
football player regulation applied today will affect the A National Football Team negatively is not completely true.

If an evaluation is made as a result of the study, in football, which is accepted as the only professional sports branch in our country, not all institutions from the federation to the clubs are professionally managed, systemic and structural problems are ignored, wrong decisions are made by focusing on shortterm success, financial resources are not evaluated rationally, and the balance of income and expenditure cannot be achieved., infrastructure and young footballers are not given the necessary value, etc. many problems can be listed. The main focus in Turkish football is not the status of foreign football players. It is necessary to make detailed analyzes for the solution of all institutional problems and to create strategic plans and to implement these plans by professionals. 